\title{
Economic Integration Agreements and the Survival of Exports
}

\author{
Kemal Türkcan \\ Akdeniz University, Antalya, Turkey \\ Hülya Saygil1 \\ Central Bank of the Republic of Turkey, Ankara, Turkey
}

\begin{abstract}
This study investigates how various Economic Integration Agreements between Turkey and its trading partners affected the exports of machinery during 1998 2013. In addition, it differentiates between trade in parts and components and finished products, and assesses the effects of Economic Integration Agreements separately on these two types of goods. Using a discrete-time probit model with random effects, we show that an Economic Integration Agreement increases the survival of export relations which were initiated before the agreement. It is found to be reasonably heterogeneous, that is, the effect is found to be larger for parts and components exports occurring within the Global Production Networks compared to finished products exports.
\end{abstract}

JEL Classification: F10, F14, C41

Keywords: Economic Integration Agreements, Export Duration, Fragmentation, Global Production Networks, Parts and Components, Survival Analysis

\footnotetext{
* Corresponding Author: Kemal Türkcan; Department of Economics, Faculty of Economics and Administrative Sciences, Akdeniz University, Dumlupınar Bulvarı 07058, Antalya, Turkey, Tel: +90 242 3106427, Fax: +90 242 2274454, E-mail: kturkcan@akdeniz.edu.tr. 


\section{Introduction}

The recent dramatic rise in the number of Economic Integration Agreements (EIAs), an important parallel development in global trade has been the rapid emergence of Global Production Networks (GPNs) (Yeats 2001, Ando 2006). Blyde et al. (2015) argued that EIAs can foster the international fragmentation of production across countries by removing nonproduction costs such as transportation, customs clearance, and other related charges. These EIA features, therefore, are expected to increase the survival probabilities of trade in Parts and Components (P\&C) because small changes in nonproduction costs have a major effect on fragmentation decisions due to the multiple border-crossings involved in a GPN. ${ }^{1}$

An interesting issue is the effects of EIAs on the survival of $\mathrm{P} \& \mathrm{C}$ trade flows linked to the rise in GPNs. ${ }^{2}$ To address this gap, the present paper considers EIA effects on the survival of export relations and makes the following contributions. First, we estimate EIA effects on export duration by using a discrete-time probit model that controls for unobserved heterogeneity among exporters, as suggested by Hess and Persson (2011a). As indicated by Martuscelli and Varela (2015), an EIA enhances the survival chances of export relations through a reduction in policy-related trading costs and additional information regarding destination markets. To accomplish this, we use Turkey's export data on machinery and transportation products at the six-digit Harmonized System (HS) level over the period of 1998 2013. Machinery and transportation equipment (MP) is one of the most significant sectors of the Turkish economy and constituted $27.3 \%$ of the total merchandise exports in 2015 (OECD 2016). ${ }^{3}$ In addition, the OECD-WTO Trade in Value Added (TiVA) database reports an increasing trend in foreign value-added content of gross exports from about $20 \%$ in 1995 up to 39\% in 2011, indicating a high degree of global production integration in the sector.

\footnotetext{
${ }^{1}$ Related literature studying the role of GPNs in enhancing the survival of P\&C export flows includes Obashi (2010) on intra-zone trade in East Asia, Shao et al. (2012) on Chinese manufacturing exports, Corcoles et al. (2014) on world auto exports, Corcoles et al. (2015) on Spain's machinery exports, and Diaz-Mora et al. (2015) on the exports of Spanish manufacturing firms.

${ }^{2}$ A few recent papers (Hayakawa and Yamashita 2011, Blyde et al. 2015) have made some progress in understanding the effects of EIAs on trade in P\&C associated with GPNs.

${ }^{3}$ In this paper, MP is denoted as HS 84 92 and composed of general machinery, electric machinery, transport equipment, and precision machinery.
} 
Second, we examine the heterogeneous effects of EIAs on the stability of export flows by including separate dummies for Non-reciprocal Preferential Trade Arrangements (NR-PTAs), Preferential Trade Arrangements (PTAs), Free Trade Agreements (FTAs), and Customs Unions (CUs). By addressing the heterogeneous nature of EIAs, we aim to show the types of agreements that are most important for enhancing the stability of export flows, as suggested by Kamuganga (2012) and Recalde et al. (2016). Third, as a key contribution of the present paper, we further decompose the total machinery exports into Finished Products (FPs) and P\&C exports to assess the role of GPNs in determining the impact of EIAs on the probability of P\&C export ceasing. We argue that by reducing trade costs, EIAs can foster the creation of GPNs, which in turn will lead to higher export survival rates in P\&C compared to FPs (Obashi 2010, Blyde et al. 2015). Finally, as a robustness check, we re-estimate EIA effects on the duration of P\&C trade associated with GPNs using an alternative proxy. However, using trade in $\mathrm{P} \& \mathrm{C}$ as a proxy for GPNs in empirical analyses may lead to overestimating EIA effects. Thus, we introduce an indicator of Vertical Differentiation (VD) as a GPN proxy into the duration analysis to more accurately evaluate EIA impacts on the stability of trade relations in P\&C linked with GPN, using the method first proposed by Abd-el-Rahman (1991) and used by Greenaway et al. (1994, 1995).

Investigating the Turkish case is important for several reasons. First, Turkey has achieved a striking record of export growth since the advent of trade liberalization in the 1980s and establishment of a CU with the European Union (EU) in 1995. ${ }^{4}$ The export volume grew at nearly 15\% per year from 1998 to 2013, which is significantly higher than the world average, but lower than that of China (World Bank 2014b). During this period, Turkey has also successfully diversified its export base and much of this progress has occurred through the destination dimension (World Bank 2014b, Aldan and Çulha 2016). Meanwhile, Turkey has intensified its participation in GPNs since 1995 (Kaminsky and Ng 2006, World Bank 2014b, Gündoğdu and Saracoğlu 2016), and aggressively pursued EIAs with its recent trade partners. Currently, Turkey is negotiating 13 further trade agreements and is planning negotiations for new trade agreements with 10 further

\footnotetext{
${ }^{4}$ Not surprisingly, the impact of the CU between the EU and Turkey on bilateral trade flows has been extensively investigated in the literature. Examples of these studies are Antonucci and Manzocchi (2006), Nowak-Lehmann et al. (2007), Neyapt1 et al. (2007), Adam and Moutos (2008), Y1lmaz (2011), World Bank (2014a), Magee (2016), and Frede and Yetkiner (2017). Despite the vast literature, there is no general consensus concerning the benefits of CU for Turkey's exports. While a few studies have revealed a negative or no significant relation between the CU and Turkey's exports (World Bank 2014a, Frede and Yetkiner 2017), others suggest a positive relation of varying magnitude (Nowak-Lehmann et al. 2007, Neyaptı et al. 2007). After reviewing the existing literature, Y1lmaz (2011) concluded that the CU generally has a beneficial effect on Turkey's export flows in the long run, largely by virtue of continuing improvements in productivity.
} 
countries including the US, Canada, and Japan. ${ }^{5}$ Overall, Turkey is a particularly appropriate country for studying EIA effects associated with internationally fragmented production, not only the noticeable improvements in its export diversification but also the increase in its ties with GPNs and the sharp rise in the number of EIAs, particularly FTAs.

We show that the survival rates of trade vary across the types of EIAs and products and EIAs have a significant effect on the likelihood of the hazard of trade ceasing. In addition, we find that EIA effects is larger on P\&C trade and becomes stronger as the trade relation involves more vertically differentiated goods. This paper is organized as follows. Section II reviews the literature. Section III describes the data used. Section IV lays out the empirical methodology, and Section V presents the empirical results including robustness checks. Finally, Section VI concludes.

\section{Literature Review}

Existing empirical studies have investigated the impacts of EIAs on aggregate bilateral trade flows rather than directly estimating the impacts on members' welfare, because the latter cannot be easily evaluated due to data limitations. To assess EIA effects on trade between member countries, most researchers have relied on gravity models and a pair of dummy variables measuring each pair of countries' participation in EIAs. Previous studies based on gravity models have yielded various results, depending on the specification of the gravity equation, time period, sample, particular EIAs considered, and the level of data aggregation (Freund and Ornelas 2010). However, Ghosh and Yamarik (2004) found a consensus that EIAs are trade creating (Aitken 1973, Bergstrand 1985, Frankel et al. 1995, Clausing 2001). A number of more recent studies, including Carrere (2006), Baier and Bergstrand (2007), Magee (2008), and Egger et al. (2008), have addressed the endogeneity problem and reached the same conclusion as the foregoing consensus view: EIAs do increase bilateral trade flows.

While the debate concerning whether EIAs foster trade flows continues, two new lines of research have emerged that significantly deepen the understandings of these

\footnotetext{
For a detailed list of the FTAs signed by Turkey, see http://www.ekonomi.gov.tr/sta/.
} 
agreements' impact on member countries. The first line of research is based on the heterogeneous firm trade theory developed by Melitz (2003), which examines the relative contribution of the extensive margin and intensive margin to export dynamics. The increasing availability of highly detailed country-level trade statistics and firm-level trade data enables researchers to measure the role of both margins in export growth ( Hummels and Klenow 2005). Subsequently, several studies have relied on disaggregated trade flows to examine EIA effects on trade flows decomposed into extensive and intensive margins. Examples include Foster et al. (2011), Egger et al. (2011), Baier et al. (2014), and Florensa et al. (2015). ${ }^{6}$ Using the decomposition method of Hummels and Klenow (2005) and the Baier and Bergstrand (2007) approach for estimating EIA effects on trade flows, Baier et al. (2014) investigated the effects of various EIAs on trade margins and found that the formation of an EIA has significantly positive effects on both extensive and intensive margins. They further found that deeper EIA types have a larger impact on both extensive and intensive margins than shallower agreements. Finally, they showed that the effect of EIAs on intensive margins is higher in magnitude than that on extensive margins. Moreover, intensive margins of trade respond sooner than extensive margins for deeper EIAs. ${ }^{7}$

The second line of research emanated by Besedes and Prusa (2006a), which examines the duration of trade relations using survival analysis. Based on Kaplan-Meier estimates of survival functions, the authors showed that the duration of US imports is very short, with the median being 2 4 years. ${ }^{8}$ In a follow-up paper (Besedes and Prusa 2010), the roles of extensive and intensive margins in export growth were further explored and most export relations are very short-lived, with the median being 1 2 years. More importantly, export growth mainly occurs through the survival and deepening of existing trade relations rather than the creation of new trade relations, i.e., the extensive margin.

Subsequent research has examined various factors influencing the length of trade relations. The factors considered as determinants of export duration include a range of variables from firm/product/market characteristics and search costs to the usual gravity model variables (Besedes and Prusa 2006b, Nitsch 2009, Brenton et al. 2010, Obashi 2010, Hess and Persson 2011b, Fugazza and Molina 2016). Besides these factors, the

\footnotetext{
${ }^{6}$ Baier et al. (2014) provided convincing arguments to support the idea that an EIA has different effects on extensive and intensive margins.

${ }^{7}$ While this finding is in line with Egger et al. (2011) and Florensa et al. (2015), it contrasts sharply with the findings of Foster et al. (2011), who found that much of the trade creation effect of preferential trade agreements takes place along the extensive margin.

${ }^{8}$ These early findings were generally confirmed by more recent evidence, including Nitsch (2009) for Germany, Hess and Persson (2011b) for EU15, and Brenton et al. (2010), for a group of developing countries.
} 
length of trade relations might also be affected by trade agreements. EIAs were expected to affect export flows not only through the direct effects of reductions in trade costs on demand, but also through the indirect effects of facing less competition. Therefore, the reduction in trade costs and the restriction on competition from countries outside the agreement can render the trade relations more stable, thereby substantially increasing the likelihood of survival in export markets (Besedes and Blyde 2010).

However, the literature that focuses exclusively on the role of EIAs in enhancing the survival of trading relations has only recently begun to emerge (Besedes and Blyde 2010, Kamuganga 2012, Besedes 2013, Besedes et al. 2015, and Recalde et al. 2016). ${ }^{9}$ The first attempt to analyze EIA impacts on the duration of export relations was made by Besedes and Blyde (2010), who analyzed factors affecting the export survival of Latin American countries during 1975 2005; they showed that pairs of countries with FTAs tend to exhibit higher survival rates than those without FTAs. Kamuganga (2012) analyzed the impacts of various EIAs on the duration of export relations involving 53 African countries during 1995 2009 and found evidence supporting that intra-regional trade cooperation in Africa increases the likelihood of export survival across all types of agreements. As for specific EIAs, the results show that deeper trade agreements such as monetary unions, Common Markets (CMs), and CUs have relatively higher survival rates than shallower PTAs. Besedes (2013) assessed the effect of the North American Free Trade Agreement (NAFTA) on the hazard of export ceasing for the three-member countries using two dummy variables capturing EIA effects, instead of only one such variable. One, NAFTA, simply represents the presence of NAFTA membership between country pairs, while the other, NAFTA in effect, captures the time effect of NAFTA on export survival over time. Besedes (2013) showed that the presence of NAFTA reduces the hazard rate of Canadian and U.S. exports to fellow NAFTA members, while it has no effect on Mexican exports. Furthermore, estimation results suggest that, contrary to expectations, NAFTA, once implemented, increased the hazard rate of Mexican and U.S. exports to other NAFTA members, but had insignificant effects in the case of Canada, contrary to expectations.

In a later study, Besedes et al. (2015) conducted one of the most comprehensive inquiries in this area by investigating EIA effects on the duration of trade flows for a sample of 180 countries from 1962 to 2005 . They argued that studies should consider the

\footnotetext{
9 Other studies examining the impacts of trade liberalization on the hazards of trade using dummy variables for EU membership are available (Brenton et al. 2010, Nitsch 2009, Hess and Persson 2011b), but were unable to consider various EIAs and failed to consider the dynamic effects of EIAs.
} 
timing of the agreement relative to that of trade relations, which can play an important role in understanding their effects on product-level patterns of trade. In doing so, several EIA dummies were added in the models to capture the dynamics associated with EIA implementation with respect to a given spell. Their results suggest that EIAs exert a dual effect on the survival of trade relations. They increase the survival of trade relations that started before the agreement, but reduce that of trade relations that started after the agreement.

More recently, Recalde et al. (2016) conducted research similar to that conducted by Besedes et al. (2015) to examine whether deeper EIAs enhance the survival of trade relations more strongly than shallow variants, using export data for 150 Latin American countries between 1962 and 2009. The signs and magnitudes of EIA impact, however, appear to differ significantly from those reported in Besedes et al. (2015). In particular, the results in Recalde et al. (2016) indicate that while the shallower EIAs reduce the survival of export relations for the spells that started before the agreement, the deeper EIAs, namely FTAs or CUs, increase the survival of export relations. In contrast, for spells that start after the agreement is enforced, the shallower agreements actually reduce the stability of export relations, while the deeper EIAs appear to exert a positive effect on the survival of export relations. Finally, their estimates suggest that survival rates increase over time after the signing of an EIA for spells commencing before and after the agreement, though the coefficient is larger in magnitude for deeper EIAs. Thus, they concluded that the formation of an EIA on the survival of trade relations may vary considerably across regions and types of EIAs.

Taken together, these studies show that EIA effects on aggregate trade flows, trade margins, and trade survival vary widely across agreements. Since the impacts of various EIAs on P\&C exports have not hitherto been investigated in the literature, the remainder of this paper seeks to fill this gap. 


\section{Data and Analysis}

Data on Turkish machinery and transportation equipment (MP) are taken from BACI, an international trade database developed by CEPII. ${ }^{10}$ Our dataset contains bilateral trade values and quantities of exports and imports at the 6-digit HS level (revision 1996) for more than 200 trade partners from 1998 to 2013.

In this product classification, there are more than 5,000 product lines covering all articles in trade (HS chapters 1 92). Following Kimura and Obashi (2010) and Obashi (2010), we identify product lines included in any of the headings of chapters 84 92 as MP (general machinery HS 84, electric machinery HS 85, transport equipment HS 86 89, and precision machinery HS 90 92). These industries are selected because they are often considered highly fragmented. Accordingly, out of the 1124 product lines, 729 and 445 are listed as FPs and P\&C, respectively. We examine exports of each product to 188 countries, which account for more than $90 \%$ of Turkey's machinery exports. The selection of the sample countries is dominated by the availability of data for bilateral trade flows and explanatory variables. The list of countries is presented in Appendix 1.

Export duration is measured by the length of spells and the number of years in which the product-country pair export relation is active. An export relation may stop and start several times over the study period, resulting in multiple spells within one export relation. The greater the number of spells, the shorter is the duration of export spells. Thus, the number of export spells may exceed that of export relations during the study period. The maximum number of spells possible for each importing country and product pair during 1998 2013 is eight.

Data on the various EIAs-our key explanatory variable-are mainly taken from Baier and Bergstrand's website, ${ }^{11}$ and supplemented by data from the WTO's Regional Trade Agreements Information System (RTA-IS). ${ }^{12}$ The database records the economic integration of bilateral country pairings for 195 countries annually from 1950 to 2012 and identifies six types of trade agreements by their level of economic integration, ranging in depth from NR-PTA to more extensive agreements such as PTAs, FTAs, CUs, CMs, and Economic Unions (EU). Our analysis focuses on the 1998 2013 period and considers

\footnotetext{
${ }^{10}$ See Gaulier and Zignago (2010) for a detailed description of this database.

${ }^{11}$ This dataset is available on Jeffrey Bergstrand's website: www.nd.edu/jbergstr.

${ }^{12}$ The database is available on the World Bank website: http://rtais.wto.org/UI/PublicMaintainRTAHome.aspx.
} 
only the first four types since the latter two types are not present throughout this period. The complete list of EIAs signed by Turkey is given in Appendix 2.

\section{Table 1. Number of observations}

\begin{tabular}{|l|c|c|c|c|}
\hline \multirow{2}{*}{} & \multicolumn{2}{|c|}{ Finished Products } & \multicolumn{2}{c|}{ Parts and Components } \\
\cline { 2 - 5 } & $\begin{array}{c}\text { Number of } \\
\text { Observations }\end{array}$ & $\begin{array}{c}\text { Percent of } \\
\text { Observations }\end{array}$ & $\begin{array}{c}\text { Number of } \\
\text { Observations }\end{array}$ & $\begin{array}{c}\text { Percent of } \\
\text { Observations }\end{array}$ \\
\hline No agreement & 142,715 & 47.01 & 122,131 & 47.47 \\
\hline EIA & 160,849 & 52.99 & 135,167 & 52.53 \\
\hline NR-PTA & 13,341 & 4.39 & 12,535 & 4.87 \\
\hline PTA & 23,820 & 7.85 & 17,830 & 6.93 \\
\hline FTA & 46,333 & 15.26 & 36,729 & 14.27 \\
\hline CU & 77,355 & 25.48 & 68,073 & 26.46 \\
\hline Total & 303,564 & 100.00 & 257,298 & 100.00 \\
\hline
\end{tabular}

(Note) This table reports the number of observations across product groups, broken down by the type of trade agreements. EIA denotes Economic Integration Agreement, NR-PTA denotes Non-reciprocal Preferential Trade Arrangements, PTA denotes Preferential Trade Arrangements, FTA denotes Free Trade Agreements, and CU denotes Customs Unions.

(Source) Authors 'own calculations based on CEPII's BACI database.

There are a total of 560,862 trade observations on MP export flows during the analysis period. Of these, about 53\% $(296,016)$ are accomplished by trade agreements and belong to the aforementioned four types of agreements (Table 1). Of the total, 303,564 observations (54\%) pertain to FP exports, while the remaining $46 \%$ pertain to $\mathrm{P} \& \mathrm{C}$. CU, accounting for about $26 \%$ of all observed trade agreements, can be considered the most common type of EIA for all types of products, followed by FTA with about $15 \%$ and PTA with about $7 \%$ of the observations. This is not surprising, given the deep and longstanding trade ties between Turkey and EU member states. Moreover, the shares of CU and NR-PTAs are higher for P\&C trade compared to FPs. 
Table 2. Average duration of exports

(Years)

\begin{tabular}{|l|c|c|c|c|}
\hline \multirow{2}{*}{} & \multicolumn{2}{|c|}{ Finished Products } & \multicolumn{2}{c|}{ Parts and Components } \\
\cline { 2 - 5 } & \multicolumn{2}{|c|}{ Length of Spells } & \multicolumn{2}{c|}{ Length of Spells } \\
\cline { 2 - 5 } No agreement & Mean & Median & Mean & Median \\
\hline EIA & 2.97 & 1 & 3.54 & 1 \\
\hline NR-PTA & 2.95 & 1 & 3.85 & 2 \\
\hline PTA & 2.60 & 1 & 3.48 & 1 \\
\hline FTA & 2.51 & 1 & 2.90 & 1 \\
\hline CU & 2.99 & 1 & 3.77 & 2 \\
\hline Total & 3.11 & 1 & 4.22 & 2 \\
\hline
\end{tabular}

(Note) This table reports the length of spells (in years) for each type of trade agreement and each product group. EIA denotes Economic Integration Agreement, NR-PTA denotes Non-reciprocal Preferential Trade Arrangements, PTA denotes Preferential Trade Arrangements, FTA denotes Free Trade Agreements, and CU denotes Customs Unions.

(Source) Authors' own calculations based on CEPII's BACI database.

Table 2 presents the length of spells for each type of trade agreement and each product group during 1998 2013. It shows that the average duration of FP export flows to EIA partners is slightly lower than those to non-EIA partners. On the other hand, Turkey's P\&C exports to EIA partners have longer spells than those to non-EIA partners. This result reinforces the hypothesis that EIAs have a stronger impact on P\&C than FP trade. Not surprisingly, the mean spell length is longest when the EIA is a CU type (3.11 years for FPs and 4.22 for $P \& C$ ). In contrast, the lowest average spell duration is found when the EIA is a PTA type for both types of products. It seems that deeper EIAs increase the length of the export spell by reducing trade-related transaction costs. We also find that CU has had the greatest impact on the duration of P\&C exports (4.22 years), because the reduction in trade costs has been greater and Turkish firms have been strongly integrated into European value chains over the past 15 years. Tables 3 and 4 show that spells of exports in $\mathrm{P} \& \mathrm{C}$ are longer than those in FPs. EIA increases the spell length, and the increase is higher when the EIA is a CU. The share of the observed spells of P\&C (FP) trade within a year or less decreases from 51 (56)\% with non-agreement to $44(53) \%$ with CU. 




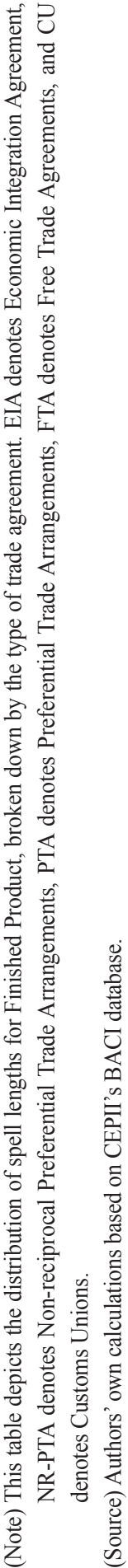




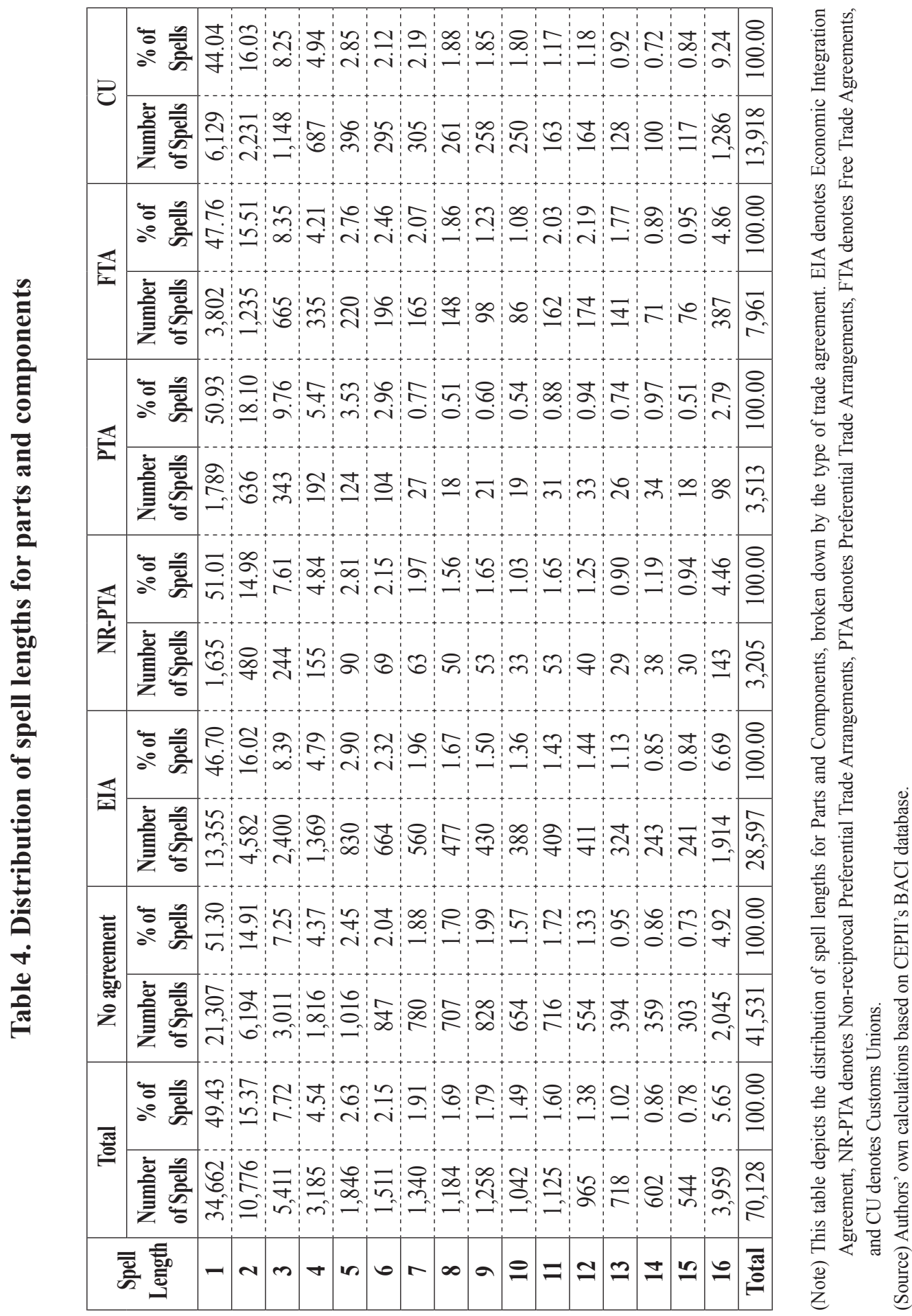


Another method of illustrating the patterns and differences in export duration across various EIAs is to graph the survival curves using the Kaplan-Meier method to estimate the probability of export relations surviving for a given number of years. The survival curves in Figures 1 and 2 show significant differences in survival rates between Turkey's machinery exports to EIA partners and those to non-EIA partners. In particular, they confirm that exports to EIA partners exhibit higher probabilities of survival than those to non-EIA partners and the gap between those two survival curves widens over time. The gap is more pronounced in the case of $\mathrm{P} \& \mathrm{C}$ than in the case of FPs. Figures 3 and 4 show separate Kaplan-Meier survival curves for various EIAs with different product groups. Surprisingly, the PTA type has higher survival rates, while the FTA type has much lower survival rates. These findings are reasonably consistent across different product groups. However, this result contradicts those of previous findings in the literature, as deeper EIAs usually lead to higher survival rates. This contradictory finding may be because Turkey's PTAs (both NR-PTA and PTA)-involving key trading partners such as the US, Japan, and Australia-are long-standing, and therefore, not only promote export experience but also improve the chances of export survival. In contrast, these relatively low survival rates for the FTA type can be attributed to the fact that Turkey's FTAs mostly involve smaller countries and are too recent to have an appreciable impact on the duration of exports.

Overall, we find that the survival rates for Turkey's exports to EIA partners are significantly higher than those for its exports to non-EIA partners and this difference in survival rates is noticeably more prevalent in the case of $\mathrm{P} \& \mathrm{C}$ exports. In the rest of the paper, we attempt to explain these findings using formal econometric analysis. 
Figure 1. Export survival for finished product

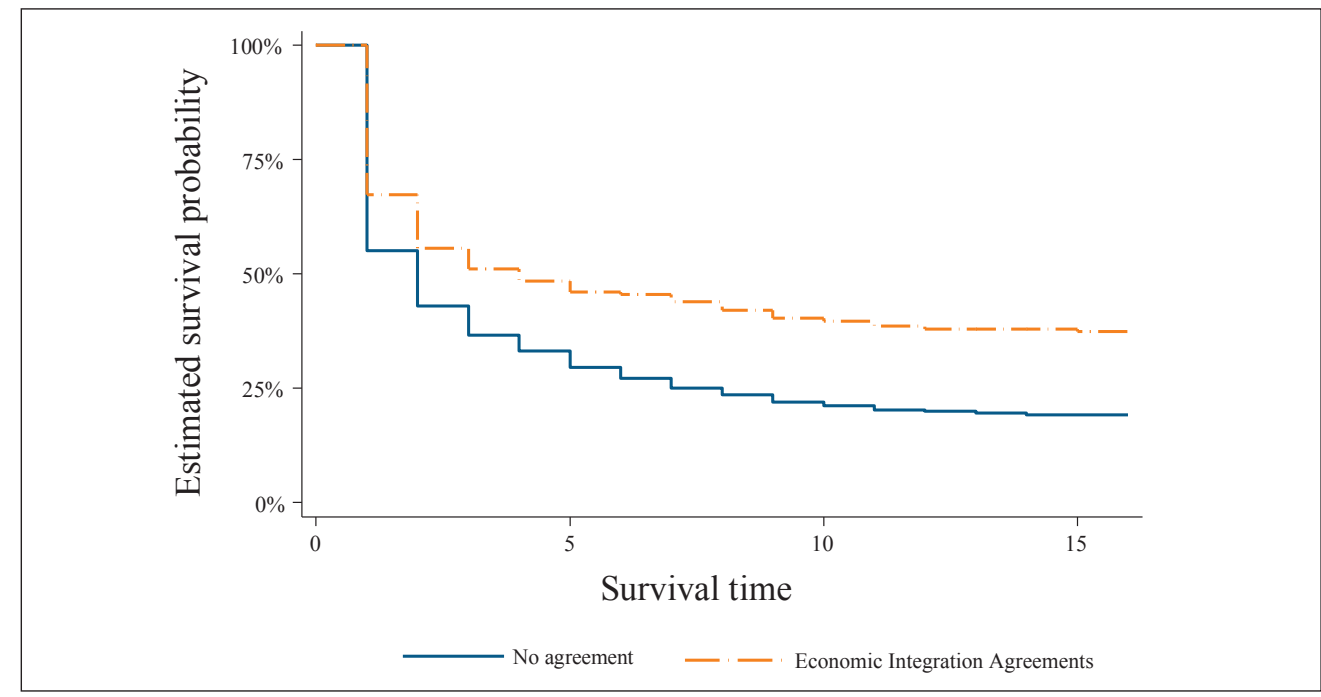

(Source) Author's own calculation based on CEPII's BACI database

Figure 2. Export survival for parts and components

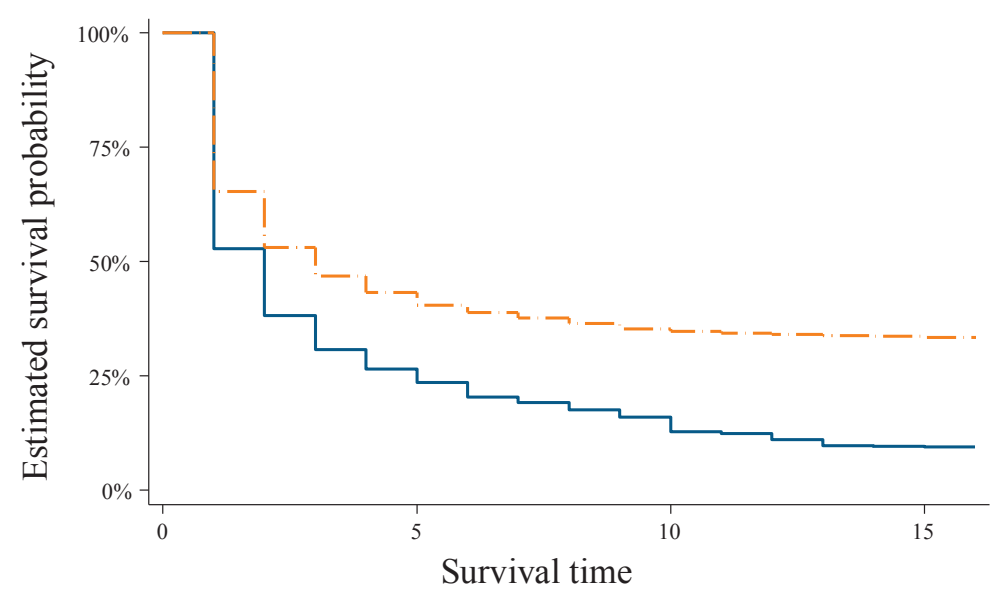

(Source) Author's own calculation based on CEPII's BACI database 


\section{Figure 3. Export survival of finished product}

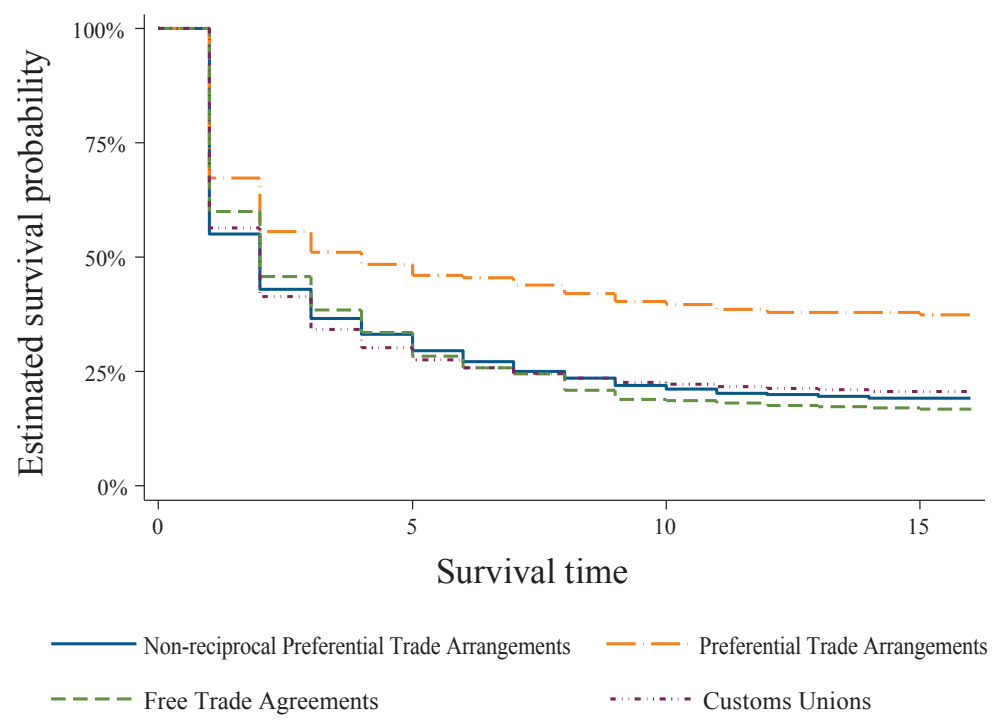

(Source) Author's own calculation based on CEPII's BACI database

Figure 4. Export survival of parts and components

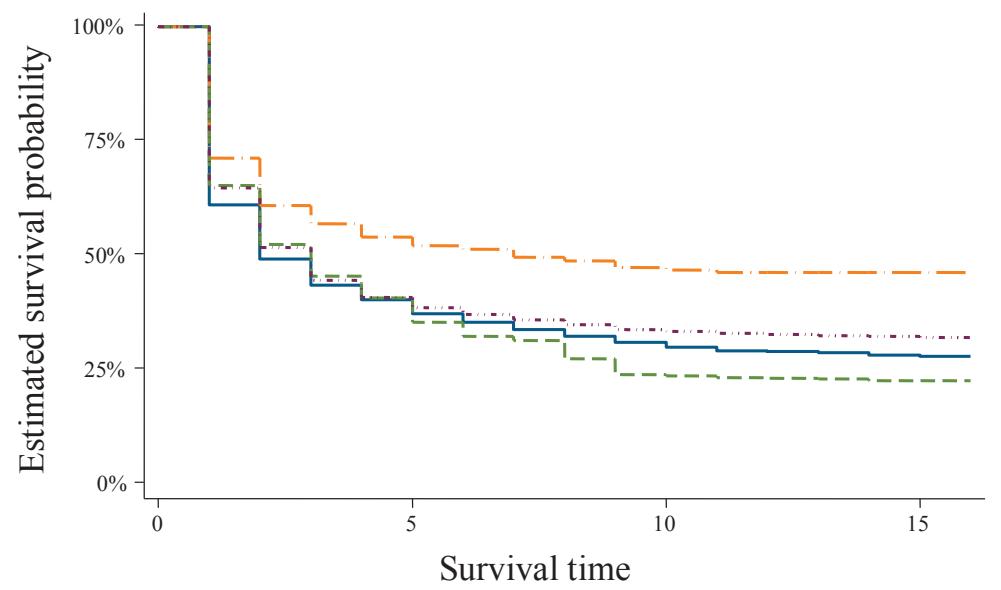

\footnotetext{
— Non-reciprocal Preferential Trade Arrangements _ _ - Preferential Trade Arrangements

(Note) This figure displays export survival probabilities of Parts and Components across four types of trade agreements using the Kaplan-Meier survival functions. NR-PTA denotes Non-reciprocal Preferential Trade Arrangements, PTA denotes Preferential Trade Arrangements, FTA denotes Free Trade Agreements, and CU denotes Customs Unions. (Source) Authors' own calculation based on CEPII's BACI database 


\section{Estimation Methodology}

\section{A. Methodology}

Following Hess and Persson (2011a), this study employs a discrete-time probit model with random effects. Discrete-time hazard models can be specified in terms of conditional probabilities of termination of a particular trade relation in a given time interval. Using the same notation as in Hess and Persson (2011a), we define $T_{i}$ as a continuous, non-negative random variable measuring the survival time of a particular trade relation. The hazard probability is then defined as the probability of terminating a trade relation within a specified time interval $\left(t_{k}, t_{k+1}\right), k=1,2, \ldots, k^{\max }$ and $t_{1=0}$ , given that failure has not occurred prior to the starting time of the interval and the explanatory variables are added to the regression model. This conditional probability can be expressed as a discrete-time hazard rate:

$$
h_{i k}=P\left(T_{i}<t_{k+1} \mid T_{i} \geq t_{k}, x_{i k}\right)=F\left(x_{i k}^{\prime} \beta+\gamma_{k}\right)
$$

where $x_{i k}$ is a vector of time-varying covariates that are assumed to affect the hazard rate and $\beta$ is a vector of coefficients to be estimated. A positive (negative) sign of coefficients indicates a higher (lower) likelihood of terminating an export relation, and consequently, lower (higher) probability of surviving in the export market. $\gamma_{k}$ is a function of time interval that allows the hazard rate to vary across periods, and $\mathrm{F}$ (.) is an appropriate distribution function ensuring that $0 \leq h_{i k} \leq 1$ for all $i, k$. In this study, denotes separate export spells for any given importer-product combination. In addition, since the underlying baseline hazard is unknown in practice, a set of dummy variables marking the length of each spell, denoted by $\gamma_{k}$, is included in the regression model.

The discrete-time proportional hazards model can be estimated by maximizing the following log-likelihood function:

$$
\ln \mathcal{L}=\sum_{i=1}^{n} \sum_{k=1}^{k_{i}}\left[y_{i k} \ln \left(h_{i k}\right)+\left(1-y_{i k}\right) \ln \left(1-h_{i k}\right)\right]
$$

where $k_{i}$ refers to the terminal time period and subscript $i$ indicates that it varies with the spell. $y_{i k}$ is a binary variable and takes the value of 1 if spell is observed to cease during the $k$ th time interval, and zero otherwise. Hence, with this specification, discrete- 
time hazard models can be regarded as a sequence of binary dependent variable models. This is convenient because any standard model for binary dependent variables (such as logit, probit, or cloglog) can be applied to estimate discrete-time hazard models.

Consequently, this specification of the log-likelihood function requires the underlying export database to be changed as follows. If the spell of the $i$ th subject is completed, then the binary dependent variable assumes the unit value for the last time point $\left(T_{i}\right)$ and zero for all other time points $\left(1,2, \ldots T_{i}-1\right)$ of the interval. For example, consider that Turkey exports a given product to a particular destination country from 2000 to 2004. Such an export relation thus has a spell length of four years. With this information about spell length, the binary dependent variable takes the value of zero from 2000 to 2003 and one for the fourth year. The advantage of this approach is that it allows the inclusion of timevarying explanatory variables into the regression model (Esteve-Perez et al. 2007).

In estimating Equation (2), it is necessary to determine the functional form of the hazard rate, $h_{i k}$. As discussed in Hess and Persson (2011a), logit, probit, and complementary log-log (cloglog) models are the most common specifications for the estimation of models with binary dependent variables. The cloglog model is the discretetime counterpart of the continuous-time Cox proportional hazards model. In contrast, both logit and probit models assume non-proportional hazards. Furthermore, Hess and Persson (2011a) argued that the inclusion of random effects into the binary choice model framework is a satisfactory approach because parameter estimates are less affected by the choice of heterogeneity distribution and this approach is convenient from the computational viewpoint. We therefore estimate Equation (2) using the discrete-time probit model with random effects. However, the results remain qualitatively unchanged when using either a logit or a cloglog model. ${ }^{13}$

Unobserved heterogeneity can also be accounted for by including country and product fixed effects. However, there are several reasons to prefer a random-effects probit model over a fixed-effects probit model. First, a random-effects model is generally preferred if the outcome is binary or dichotomous. Second, a random-effects model can estimate time-invariant variables, such as distance or the economic integration dummy, which are dropped in a fixed-effects model. After obtaining the coefficient estimates from both models, a Hausman specification test is performed to determine whether the coefficient estimates of the two models are systematically different. Given the foregoing considerations and test results, we continue to analyze EIA effects on the duration of

\footnotetext{
${ }^{13}$ We omit these results here for brevity.
} 
export flows using a discrete-time probit model with random effects.

Before proceeding to the model specifications and econometric analysis, all leftcensoring spells (i.e., the export flows that are already active in the first year of the sample, namely 1998) are omitted from the analysis, reflecting common practice for handling left-censoring data (Obashi 2010, Hess and Persson 2011b, Fugazza and Molina 2016). The discrete-time probit model is estimated separately for FPs and P\&C to quantify whether model estimates differ across product types. Moreover, restricting our attention to these subsamples enables us to identify the role played by GPNs in determining EIA effects on the duration.

\section{B. Variables}

\section{Country and product-specific variables}

While we are particularly interested in analyzing EIA effects on the duration of exports, we also include various country- and product-specific control variables in our probit analysis, which have been widely used in previous trade duration studies (Hess and Persson 2011b, Corcoles et al. 2015, Besedes et al. 2015). Country-specific variables are characterized by distance, border, common language, and importers' GDP. According to the gravity literature, trade costs tend to be lower for countries that have common borders or language and are closer geographically. The decline in trade costs may in turn increase trade relations, and therefore, decrease the probability of export ceasing. Another variable that is likely to influence the survival of export flows is the importers' GDP since it serves as a proxy for market thickness. Brenton et al. (2010) argued that export relations involving economically large importers are more likely to last longer. In addition, trading partners' market size increases the opportunities of fragmentation in trade and lowers the export hazard (Jones and Kierzkowski 2001, Grossman and Helpman 2005).

Product-specific variables are represented by the natural logarithm of initial export value and lagged duration. An export relation with a larger initial transaction size reflects the existence of ex-ante trust between trading partners and might reduce export hazard (Rauch and Watson 2003). The lagged duration, i.e., the number of years that a previous export spell lasted, is included to assess the impact of export experience on hazard rate. We assume that experience in exports of a specific product is negatively associated 
with the hazard rate (Das et al. 2007, Stirbat et al. 2015). Appendix 3 provides more information on the explanatory variables and data sources.

\section{Economic Integration Agreements-related variables}

Besides gravity variables, we also include several EIA dummies in the probit model to capture the effects of trade agreements on the stability of Turkish machinery exports, which is the purpose of this paper. According to Besedes et al. (2015), thinking about EIA effects requires being cautious of an agreement time as it relates to the spells of trade. They argued that EIAs affect a firm's decision to enter or exit an export market through a reduction in marginal and fixed costs. By reducing these costs, EIAs can be expected to have dual effects on the hazard of export ceasing; these effects may proceed in the same direction or opposite directions. First, existing exporters continue exporting after the agreement is signed as these costs drop. Consequently, this implies higher survival rates for old products already active in the export markets. Second, reductions in trade costs can reduce the costs of entry and exit, and thereby, induce firms to start exporting after the agreement comes into force. Whether such a firm will be successful and keep exporting to export markets will depend largely on its productivity as well as realized profit. When export starters are highly productive, high-quality firms, then EIAs enable them to achieve a more stable stream of profits from exporting. Such firms, in turn, tend to stay in the export market for a long time. This leads to higher survival rates in any spell for products that are not exported when the agreement is enforced. On the other hand, when new exporters have low productivity and produce low-quality products, EIAs promote the entry of these low-productive firms into export markets as they find it profitable to export. Such firms would likely choose not to export when they are hit by a demand or productivity shock, which in turn increases the likelihood of exit decisions in export markets. Therefore, EIAs might increase the hazard for any spell that commences after the agreement is signed. There are then two opposing effects, whose relative magnitude determines whether the EIA reduces or increases the stability of export spells that began after the signing of the agreement. Determining which of these two effects dominates is an empirical matter.

Accordingly, to explore EIA effects on export hazard, we follow the approach suggested by Besedes et al. (2015) and create three dummy variables to adequately capture the dynamics associated with the implementation of EIAs with respect to a given spell. The first dummy, EIA exists, defines all pairs of countries that have an agreement 
at some point. The second dummy, EIA in effect, classifies the years during which an agreement is in place. The third dummy, Spell starts after EIA, identifies the spells that started after the agreement was signed. Finally, in addition to these three dummies, we add another variable, Duration of EIA, which measures how long an agreement has been in place. While Besedes et al. (2015) pooled different EIA types, for our analysis, we construct these four variables not only for the pooled EIA but also for each of the specific EIAs, namely NR-PTA, PTA, FTA, and CU. This allows us to examine heterogeneous effects of EIAs on export survival and to compare our results with those of Besedes et al. (2015).

\section{Vertical Differentiation-related variables}

As mentioned above, the objective of this study is to assess whether the establishment of a trade agreement improves the survival probability of P\&C export flows associated with GPNs. Yi (2003) claimed that fragmentation-based trade or vertically linked trade is more sensitive to changes in trading costs induced by trade agreements because the international fragmentation of production causes products to move across borders many times before reaching their final consumption location. Similarly, Obashi (2010) argued that the more advanced utilization of FTAs encourages cross-border sharing by facilitating network-forming multinationals to spread fragmented production processes more efficiently across the East Asian region, resulting in more stable trade relations. Likewise, Blyde et al. (2015) suggested that EIAs promote the formation of cross-border production networks by reducing nonproduction costs (e.g., customs procedures and technical barriers).

While the theory posits a clear relation between EIAs and the duration of fragmentationbased export flows, measurement of the international fragmentation of production is not straightforward since the required data are not readily available; thus, empirical studies need to rely on proxy measures for trade-related global production sharing activities. Several studies have attempted to measure the degree of fragmentation or production sharing. These studies can be divided into four groups based on their methods and the data sources employed. The first group uses fragmentation indicators based on inputoutput tables (Campa and Goldberg 1997, Feenstra and Hanson 1996, Hummels et al. 2001). Other studies, represented by Görg (2000), Egger and Egger (2005), and Clark (2006), employ fragmentation indicators based on outward and inward processing trade statistics. Another group of studies measures the degree of fragmentation by using 
intra-firm trade statistics (e.g., Andersson and Fredriksson 2000, Kimura and Ando 2005). Finally, some analysts suggest using international trade statistics to estimate fragmentation by simply calculating the volume of trade in P\&C (Yeats 2001, Kimura et al. 2007) or the vertical Intra-Industry Trade (IIT) index (Ando 2006) in intermediate goods.

More recently, the availability and utilization of global input-output tables have led to significant methodological contributions for measuring the degree of production sharing in a particular industry. These tables have become a dominant tool for measuring international production linkages. For example, using the GTAP database, Johnson and Noguera (2012) generalized the vertical specialization concept of Hummels et al. (2001) by combining input-output and bilateral trade data to compute the value-added content of bilateral trade as a measure of cross-border production linkages. Currently, the most widely used global input-output tables are the TiVA database based on OECD/WTO national input-output tables released in 2013 and the World Input-Output Database (WIOD) released in 2012, which enable researchers to map and measure global trade in value-added networks. These three databases permit the tracking of intermediate inputs as they cross geographic boundaries and industrial processing stages en route to foreign or possibly domestic final demands. However, they have one major shortcoming that has limited the utilization of this method in the trade duration literature: they provide information only at the industry level, while what is needed for duration analysis is trade information at the product level.

Because of these limitations, we consider only two proxy measures of fragmentationbased export flows (i.e., P\&C export flows associated with GPNs) on foreign trade statistics. ${ }^{14}$ First, we follow Obashi (2010) and Corcoles et al. (2015) and use trade in $\mathrm{P} \& \mathrm{C}$ to proxy for trade linked with global production activities. We, therefore, estimate a discrete probit model for FPs and P\&C separately by relying on a P\&C product list based on Kimura and Obashi (2010), using the same covariates. However, the use of P\&C trade may pose particular challenges in evaluating the role of GPNs in shaping EIA effects on export survival. While trade statistics are undoubtedly the most accessible data for the study of trade duration, these statistics are a rather crude proxy for global production activities since they provide no information on production network activities between countries; hence, the fragmentary nature of trade in $\mathrm{P} \& \mathrm{C}$ cannot be adequately

\footnotetext{
${ }^{14}$ Ideally, intra-firm trade statistics would be used to assess the degree of fragmentation. Unfortunately, such data are also not available at the required level of detail.
} 
captured. Therefore, using trade in $\mathrm{P} \& \mathrm{C}$ as an indicator of fragmentation-based trade may lead to overestimation of the role of GPNs in assessing EIA effects on the duration of export flows.

To deal with this, in the final stage of our analysis, we offer an alternative to the conventional approach of employing trade in $\mathrm{P} \& \mathrm{C}$ as a proxy for global production sharing or fragmentation-based trade. More precisely, we introduce an indicator of vertical/horizontal differentiation as a proxy for fragmentation-based export flows into the probit analysis. The indicator adopted from the IIT literature is based on the decomposition of trade into vertical and horizontal flows. As Jones et al. (2002) and Ando (2006) suggested, international fragmentation generates IIT in P\&C between countries that may exchange one $\mathrm{P} \& \mathrm{C}$ for another $\mathrm{P} \& \mathrm{C}$, both of which are within the same industry classification. There are three possibilities that lead to two-way exchanges of P\&C: horizontal trade in similar products with differentiated varieties, trade in vertically differentiated $\mathrm{P} \& \mathrm{C}$ distinguished by quality, and vertical specialization that involves the exchange of technologically linked P\&C. Vertical IIT can be used as an indicator of international fragmentation within the same product category because it generates differences in unit values across technologically related exported and imported P\&C. This approach is supported by the findings of Jones et al. (2002), Ando (2006), and Kimura et al. (2007); these authors showed that the rapid increase in vertical IIT originates primarily from vertical linkages in production, rather than trade in qualitydifferentiated goods. Thus, we use unit-price differentials between exported and imported $\mathrm{P} \& \mathrm{C}$ as a criterion for distinguishing trade in Horizontally Differentiated (HD) $\mathrm{P} \& \mathrm{C}$ from that in technologically linked P\&C. However, note that trade flows classified as vertical IIT can also include vertical IIT with differences in quality.

The first step toward computing the Vertical Differentiation (VD) indicator is to select P\&C in the bilateral trade data, following Kimura and Obashi (2010). Next, we decompose P\&C exports into HD and VD products by using the method first suggested by Abd-el-Rahman (1991), and used by Greenaway et al. $(1994,1995)$. The idea therein is that price differentials between export prices and import prices outside a certain range reflect VD. More specifically, trade in $\mathrm{P} \& \mathrm{C}$ is considered horizontal if export and import values differ by less than $25 \%$ and vertical when the ratio of unit values falls outside the following range: ${ }^{15}$

\footnotetext{
${ }^{15}$ We also explored the robustness of results to using a $15 \%$ threshold. The results were consistent with those in the main text. For brevity, we do not report these results, but they are available from the authors upon request.
} 


$$
\frac{1}{1.25} \leq \frac{P_{j s t}^{X}}{P_{j s t}^{M}} \leq 1.25
$$

where $P_{j s t}^{X}$ and $P_{j s t}^{M}$ represent the unit value of Turkey's exports and imports, respectively; $j$ denotes the product, and $s$ denotes the partner country in year $t .^{16}$ Accordingly, the dummy variable VD takes the values of 1 if the unit price ratio lies outside the range of between 0.75 and 1.25 , and 0 otherwise. The choice of $25 \%$ is arbitrary. In the trade literature, two such values are commonly employed, $15 \%$ and $25 \%$. The $15 \%$ threshold is generally used and considered appropriate when the unit value differences reflect only differences in quality. However, in the case of global production sharing, the $15 \%$ threshold can be too wide, and thus, the $25 \%$ threshold is considered more appropriate (Ando 2006). Taking these considerations into account, this paper uses a rather narrower measure of $\mathrm{VD}$ in $\mathrm{P} \& \mathrm{C}$ to more accurately identify whether trade flows relate to GPNs.

Therefore, the indicator favored in this paper may capture multi-stage trade as a result of back-and-forth transactions in vertically fragmented production networks in the same commodity heading (Ando 2006, Wakasugi 2007). Linkages between EIAs and VD are set up by including multiplications of each of the four EIA dummies and the VD dummy in the survival analysis. The results will reveal how EIAs affect the survival rate of trade when products are VD.

\section{Empirical Results}

\section{A. Benchmarks}

Tables 5 and 6 present probit modeling results for EIA effect on export survival. All probit estimations consider three specifications to adequately capture the dynamics associated with EIA implementation with respect to a given spell. Four EIA-related variables are used in three specifications for estimating EIA effects on the duration of

\footnotetext{
${ }^{16}$ Unit values at the 6-digit HS product level are constructed as the value of imports and exports of the product divided by the corresponding quantities.
} 
exports. In this way, we allow for differential timing of EIA effects on the stability of export relations. The first specification contains two variables: EIA exists and EIA in effect. The former is intended to identify whether the hazard of trade between countries with an agreement differs from that between countries that never sign an agreement, while the latter is used to account for the differential effect of EIAs on export spells. The second specification adds a third dummy variable, Spell starts after EIA, which captures the differential effect on spells that starts after the agreement has been put into effect. Finally, the third specification adds a fourth variable, Duration of EIA, which allows us to assess whether the effect of an agreement depends on how long it has been in place.

As already noted, the effects of various EIAs on export survival may not be uniform. For this purpose, these three specifications are estimated separately for various EIAs: NR-PTAs, PTAs, FTAs, and CUs. We estimate EIA effects on export survival separately for FPs and $\mathrm{P} \& \mathrm{C}$, to understand the role that fragmentation-based export flows play in determining EIA effects on the probability of P\&C export ceasing. We use the same set of covariates, as delineated above, in each probit regression. Finally, as a robustness check of our measure of fragmentation-based trade flows, we add VD-related variables in the analysis for P\&C (Table 7).

In general, all standard variables have the expected signs and the magnitudes are similar to those found in Besedes et al. (2015), except for the results for common language. The results do not significantly vary across various EIAs, but in general, the size of the coefficients is higher in case of CU. Hazard rates decrease in border, importers' GDP, initial exports, and duration, but increase in distance. The impacts of distance and border are larger on hazard rates of FP trade, while importers' GDP, initial export value, and duration have greater influence on the hazard rates of $\mathrm{P} \& \mathrm{C}$ trade. Accordingly, being a large country and building a long and credible relation increase the duration of P\&C trade more than that of FP trade.

Interestingly, the signs and significance of the language coefficients vary depending on the type of exported products. In Table 5, for FPs, the impact is negative and significant for all types of EIAs except for Model 3 of EIA. This result is consistent with those of both Besedes et al. (2015) and Recalde et al. (2016). However, our results in Table 6 suggest that when exports involve more $\mathrm{P} \& \mathrm{C}$, the statistical significance of language no longer holds, with few exceptions. ${ }^{17}$

\footnotetext{
${ }^{17}$ Nonsignificant coefficient estimates for common language in the case of Turkey's exports may also be due to the small number of its trading partners (Cyprus and Bulgaria) fulfilling these characteristics.
} 
The results in the first three columns of Tables 5 and 6 provide strong statistical support for the notion that the existence of an EIA for a pair of countries (EIA exists) decreases the hazard of export ceasing. This effect generally holds across the three specifications when the other EIA-related dummies are added sequentially. Hence, country pairs that, at some point, have an EIA exhibit a lower hazard rate than those that have never had an integration agreement. These findings are in line with those of both Besedes et al. (2015) and Recalde et al. (2016). However, the impact of existing EIAs varies across product types. In Table 5, existing NR-PTAs and CUs do not have any significant impact on the hazard of FP export ceasing, while both existing PTA and FTA significantly reduce the hazard. Table 6 reports that the impact of existing EIAs on the hazard rate of $\mathrm{P} \& \mathrm{C}$ exports increases with the depth of agreements. While the estimated coefficients are statistically insignificant for existing NR-PTAs and PTAs, the magnitude and explanatory power of those for FTAs and CUs increase. The analysis thus confirms the intuitive argument made by Obashi (2010) that GPN benefits more from deeper trade agreements.

The sign and magnitude of the coefficient of EIA in effect depend on the inclusion of the other two dummies (Spell starts after EIA and Duration of EIA). Since we have significant results for the latter two dummies, we continue to interpret the results containing all EIA-related dummies, our third and preferred specification (column 3 of each part). Thereby, consistent with the findings of Besedes et al. (2015), the coefficients of EIA in effect are negative and significant across all EIA types, suggesting that the onset of an agreement reduces the likelihood of both FP and P\&C export ceasing (Tables 5 and 6). This conclusion adds to the findings of Recalde et al. (2016), who by using aggregate data for Latin America, found that the onset of an agreement has a significant hazard-reducing effect only when the EIA is deep enough. Our results suggest that EIA effects vary depending on the type of exported goods. Coefficient magnitudes are larger for P\&C. Indeed, the CU coefficient is not significant for FPs. Our results support the idea that by lowering trade costs, EIAs can help integrate domestic firms into GPNs and build long-lasting trading relations.

However, the third specification shows that, consistent with the results of Besedes et al. (2015), the estimated coefficient of Spells starts after EIA has either a significantly positive effect or stays neutral vis-à-vis the hazard rate. This evidence supports the view that EIAs reduce the stability of export spells that begin after the agreement is enforced. The effect differs across various trade agreements and product types, as seen in the third column of each type of EIA in both Tables 5 and 6. For FPs, the hazard rate 
is not affected if spells begin after the FTA agreements. Similarly, the positive effect on the hazard rate disappears when we consider EIA itself or PTA for P\&C. Among the significant cases, the effect of NR-PTA on export duration across all product types is greater than the effect of deeper agreements, suggesting that shallower agreements do not provide sufficient benefits to help high-cost exporters survive in the long run.

The coefficient estimates of Duration of EIA from the probit output reported in the third columns of Tables 5 and 6 are positive and statistically significant, a result similar to that obtained in Besedes et al. (2015). With the exception of NR-PTA and PTA for FPs, this effect is consistent across various trade agreements and product types. Among the significant cases, the magnitude of the FTA (CU) coefficient is larger for FPs (P\&C). This suggests that $\mathrm{CU}$ has a stronger effect on the stability of fragmentation-based export flows than any other type of EIA.

Taking all of our results together, we conclude that an EIA has a dual effect on the stability of export relations: it increases the survival of export relations that had already started when the agreement took place, but reduces the survival of those that started afterwards. These results are in line with the findings obtained by Besedes et al. (2015). 


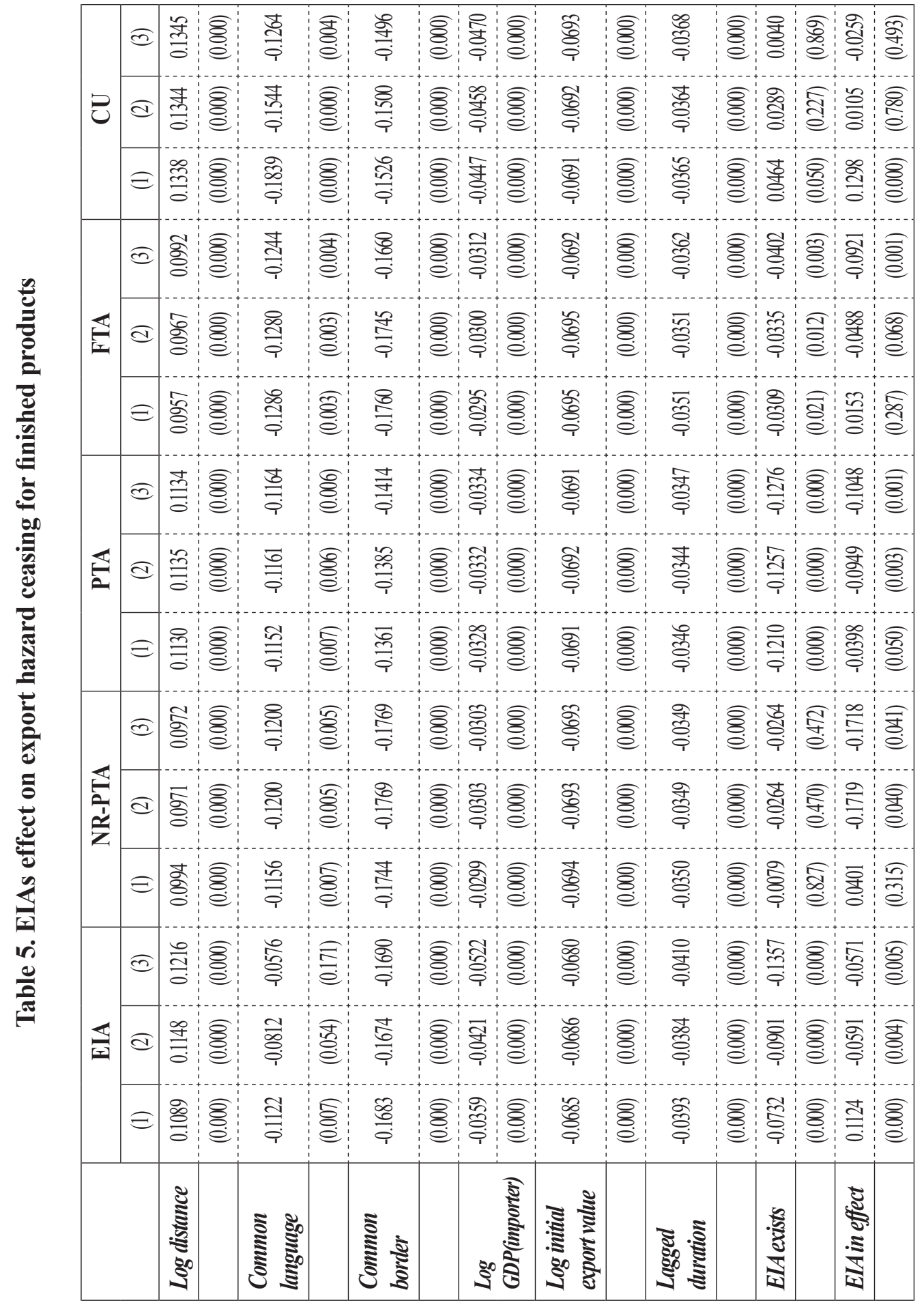




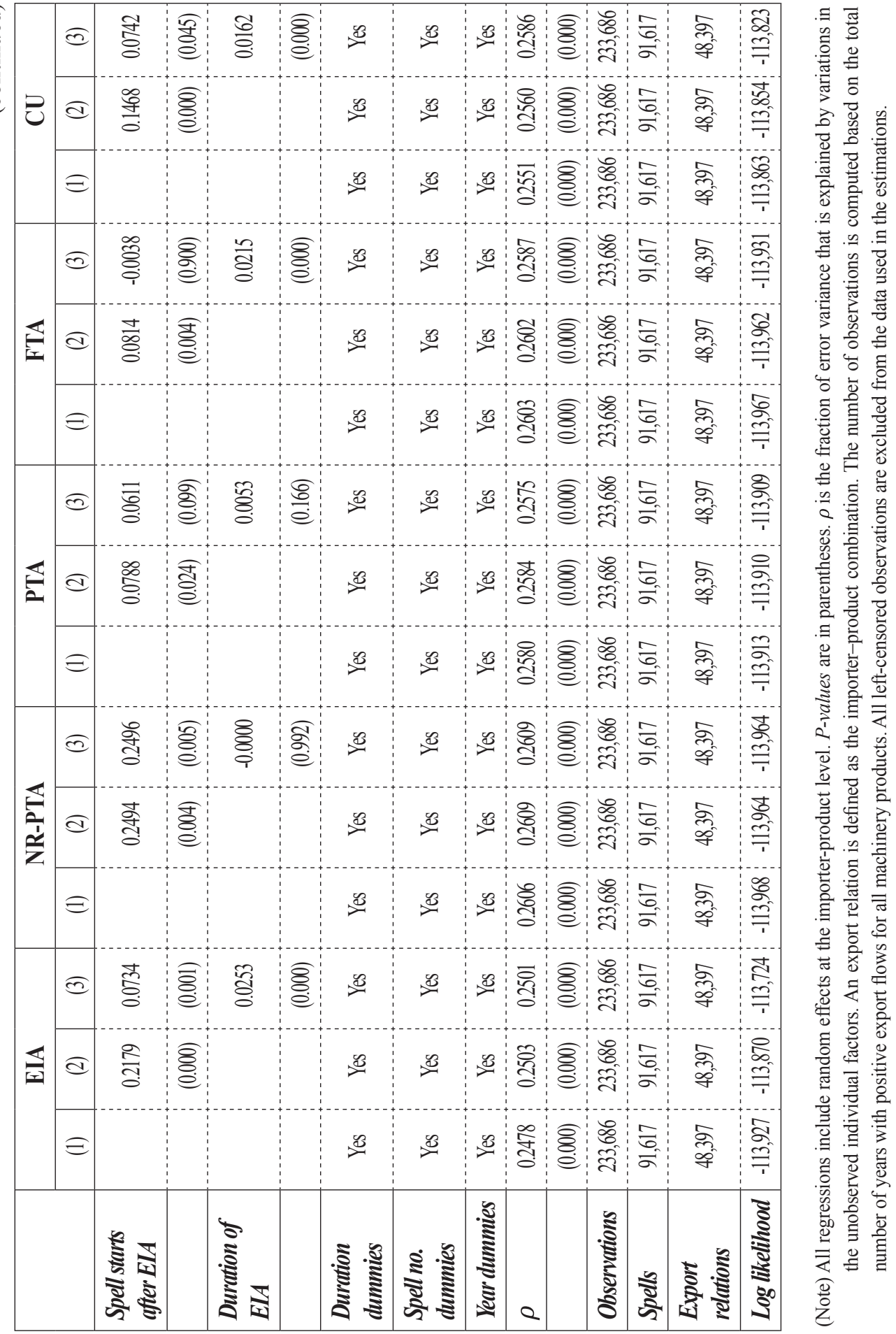




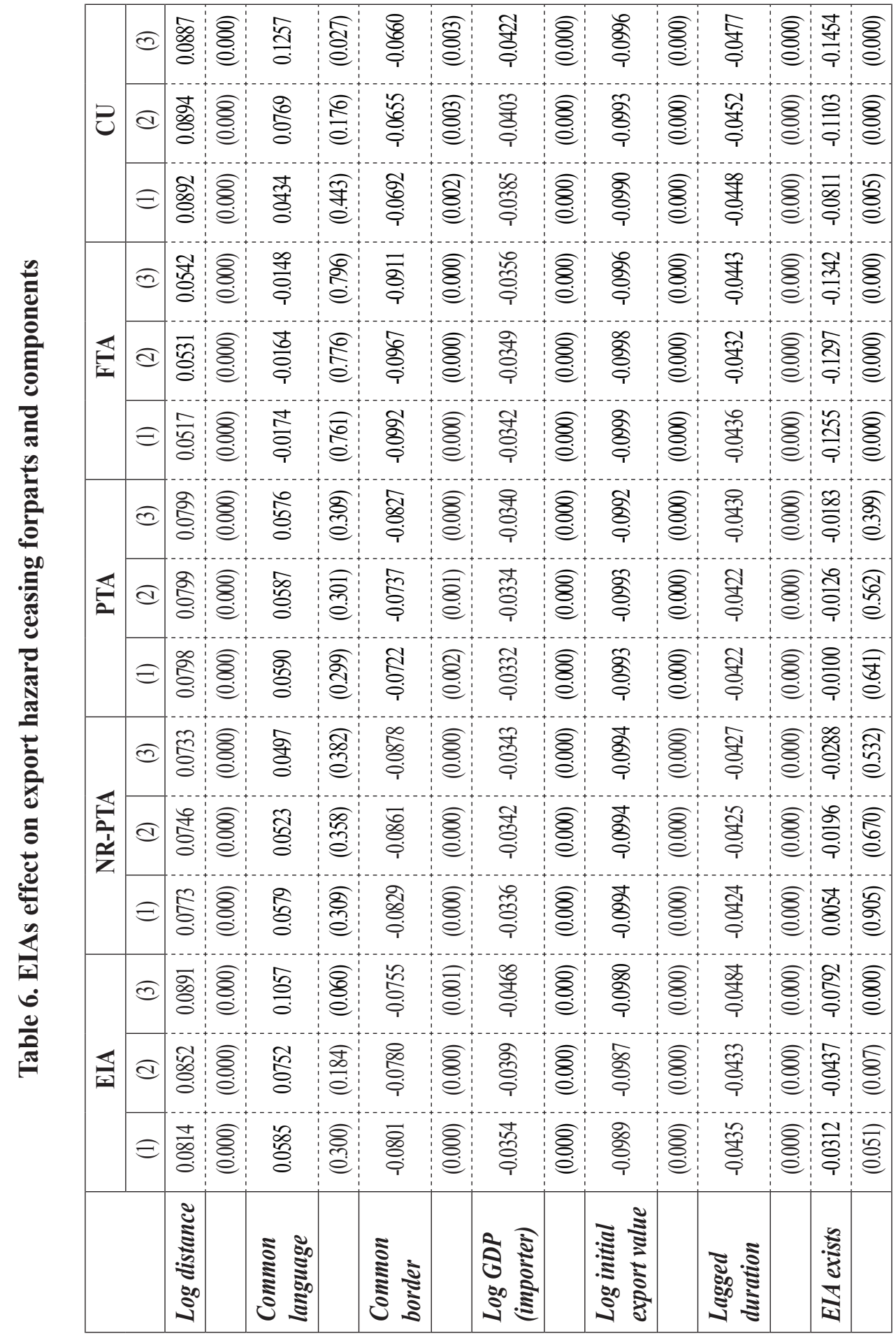




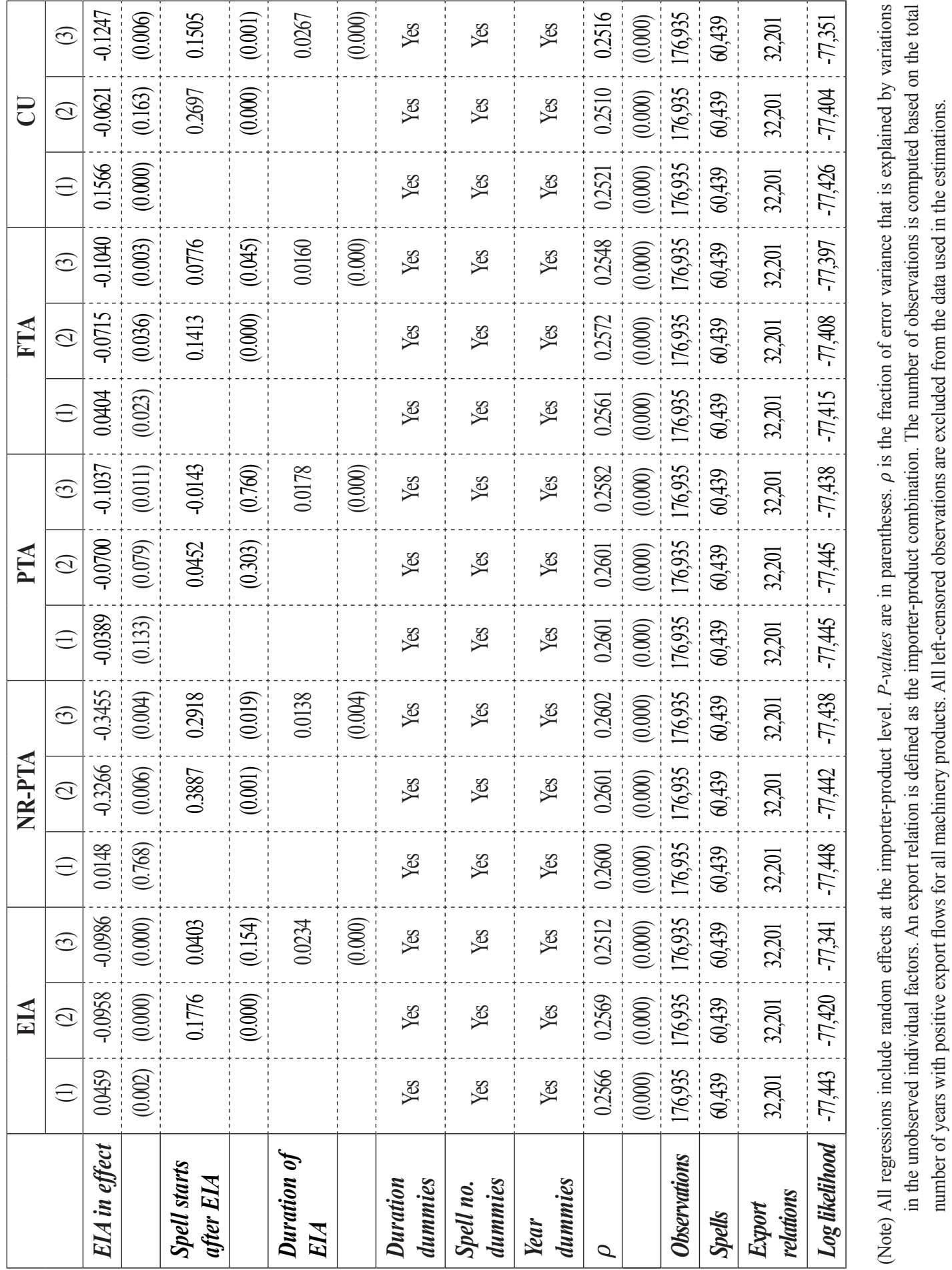




\section{B. Robustness checks}

In Table 7, we explore the robustness of our results by using an alternative measure of fragmentation-based export flows, VD. This alternative measure is particularly appealing because it enables us to accurately identify whether a P\&C item is integrated in the GPN, and therefore, to isolate or differentiate EIA effects on the duration of fragmentationbased export flows from those of other non-related party transactions. In doing so, we make the VD dummy interact with the set of EIA-related variables employed in the foregoing models. First, inclusion of interaction terms between VD- and EIA-related variables does not significantly change our benchmark results for standard gravity variables in Table 7. Hazard rates decrease in border, importers' GDP, initial exports, and duration, but increase in distance. Similar to the results in Table 6, we find no significant impact of language on the hazard rate.

Considering the EIA-related variables, we continue to interpret column 3 of each panel, and find the results to be parallel to those in Table 6, with a few exceptions. First, the coefficient of VD for P\&C is negative and statistically significant, revealing that hazard rates are substantially lower for intermediate products that are traded within GPNs. This result is robust across various trade agreements. This confirms that participation in GPNs reduces the probability of export exit, which is in line with extant empirical findings in the literature, for instance, Obashi (2010). Second, considering all EIAs together, we can observe that the direct impact of the EIA-related variables remains qualitatively the same and the magnitudes of the coefficients are only marginally reduced. In particular, the results in Table 7 indicate that the negative effect on the hazard rates of EIA exists still remains, though the effect is lower for VD products, as indicated by the significantly positive coefficient of the interaction term. When we disaggregate EIAs, we find that this result is mainly driven by the existing PTA. Furthermore, the coefficient of EIA in effect is consistent with those reported in Table 6, with a negative coefficient of interaction with VD. This means that the negative effect on the hazard rates of the agreement being enforced is more pronounced for the already active GPN-related export spells. Table 7 also shows that the coefficient of Spell starts after EIA is significantly positive and its interaction term with VD is significantly and strongly positive. The dual effects of EIAs on hazard rates appear to be greater for GPNrelated products. The coefficients representing the duration of EIA and its interaction term with VD exert a positive and significant impact on hazard rates, which indicates that the predicted probability of export exit decreases as the duration of trade agreement 
increases, and this effect seems to be more prevalent for vertically differentiated P\&C. Results obtained with the interaction effects thus far suggest that the presence of VD trade reduces the exit probability of already active spells while increasing it for any spell that begins after the agreement is enforced.

The role VD plays in the impacts of EIAs also varies across the type of trade agreements. First, the coefficients of the direct effect of NR-PTA and PTA become smaller and lose their statistical significance once the interaction terms with VD are added. In particular, the direct relation between the duration of NR-PTA and hazard rates is now insignificant. In addition, for NR-PTA-type trade agreements, VD increases the negative effects of existing EIA and positive effect of EIA duration on the hazard rate. However, none of the estimated coefficients on interactions between VD- and EIA-related variables are significant when trade agreements are of PTA type. These unexpected results regarding the effects of interaction terms with VD on hazard rates are attributable to the small sample size for these agreements. Nevertheless, the results suggest that export flows directed to NR-PTA or PTA partners are less prone to the lower trade costs brought by trade agreements since these transactions are probably not substantively related to GPNs.

The inclusion of interaction terms does not affect the direct impacts of FTA on hazard rates but weakens the effects for some EIA-related dummies; the coefficients are significant in all but one case. Furthermore, the results show that VD tends to intensify the negative relation between the existences of an agreement or the onset of an agreement and hazard rates when the agreement is FTA type, while it increases the adverse impact of trade agreements on spells commencing after the agreement takes effect. In the case of CU-type trade agreements, VD coefficients remain unaffected by the incorporation of interaction terms into the model (with one exception). However, the magnitudes of the coefficient estimates are reduced noticeably from those in Table 6. When we make CU-related dummies to interact with VD, we find that the hazard rate reducing impacts of existing EIA becomes stronger with VD. At the same time, VD does not play any significant role in the determination of the effect of the already active spells or spells starting after EIA when the agreement is a $\mathrm{CU}$, but the hazard increasing impact of the duration of EIA surges.

Overall, these robustness results vis-à-vis shallower agreements suggest a limited role of VD in explaining EIA effects on the hazard rates of P\&C, while VD appears to play a greater role for deeper trade agreements. Put simply, the evidence implies that trade agreements raise the odds of export survival of $\mathrm{P} \& \mathrm{C}$ flows if they are deep enough to support GPNs. 
ส ๖ Є ๔

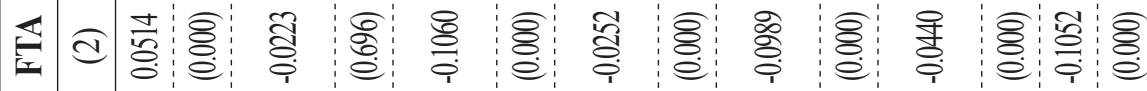

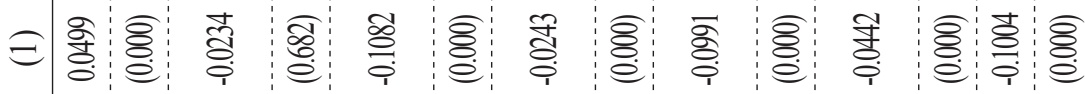

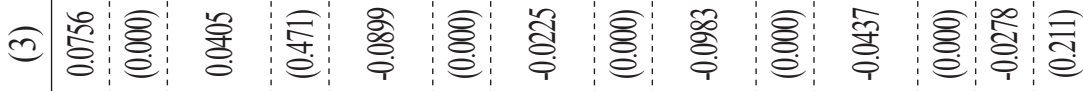

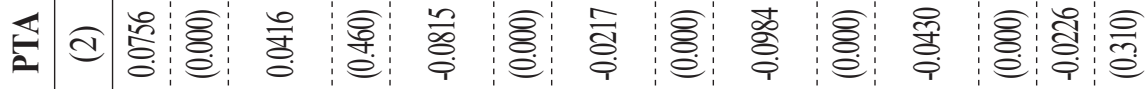
Єఓ ๙

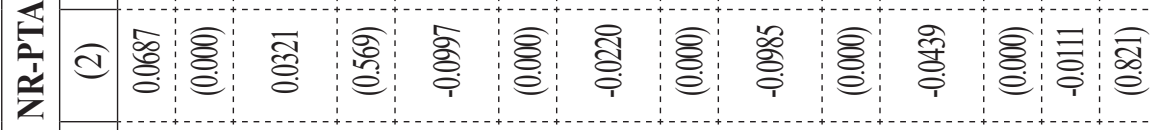
Є응 ๔

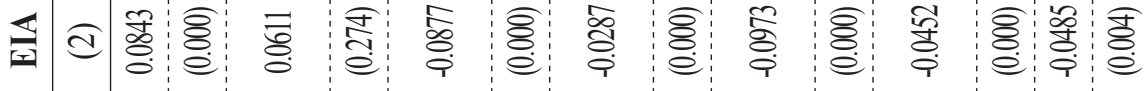
Є

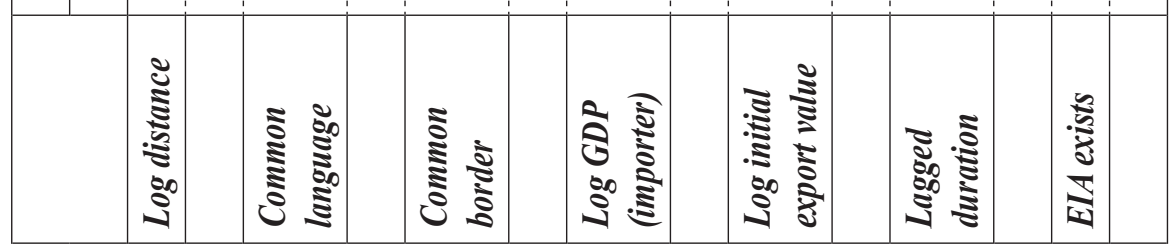




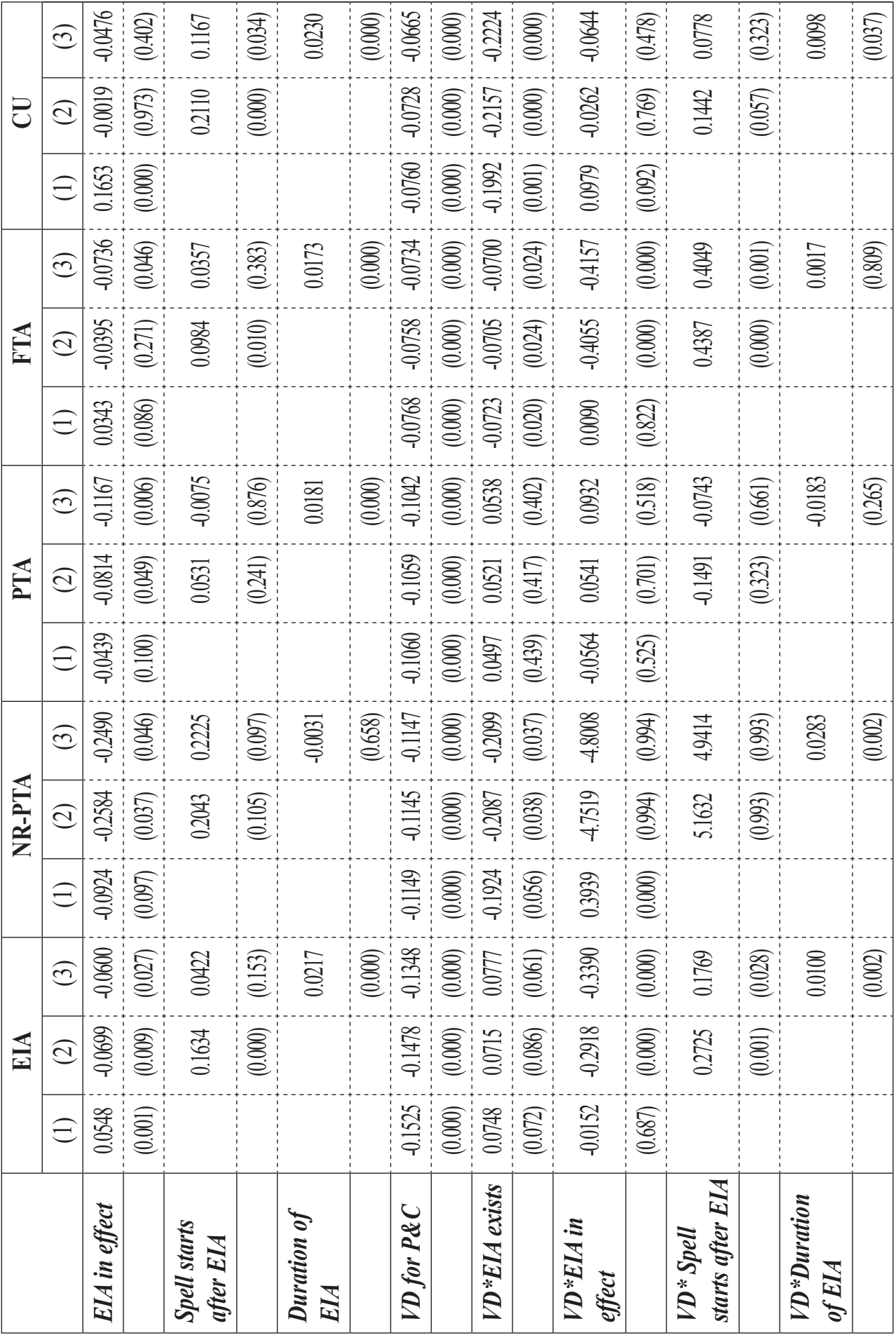









\section{Conclusion}

This paper utilizes survival analysis by using 6-digit HS data to examine EIA effects on Turkish machinery products export survival. We show that an EIA has a dual effect on the stability of export relations: it increases the survival of export relations that had already started when the agreement was enforced, but reduces the survival of those that started afterwards. In addition, we find that the impact of EIA-related variables may vary across the type of EIAs and products. Second, we demonstrate that VD has a positive and statistically significant impact on the survival rates of P\&C exports and the impact of trade agreements is larger if products are characterized by a vertically fragmented production process. The paper concludes that GPNs can be an effective way for developing countries to increase the potential benefits from EIAs in terms of export survival.

The paper emphasizes the importance of GPNs in the determination of export ceasing hazard. The depth, content, and duration of the agreements depend on the bargaining power of a country in foreign trade. Developing countries that desire to survive in foreign trade need to strengthen their bargaining power in this direction. Policies need to be designed in a way to enhance the competitiveness of the private sector and facilitate its participation in GPNs. Attractiveness of a country to domestic and foreign investors and traders needs to be increased by improving physical, social, and financial infrastructure; the quantity and quality of human capital; and technological capabilities. Productive factors should be supported to satisfy the needs and developments in GPNs.

In addition, improving the ease of doing business and building strong institutional capacity in Turkey plays an important role in establishing new partnerships while extending the duration of existing agreements. Reducing potential economic, political, and financial risks will enhance the investment climate and contribute to the survival of export relations.

The results in this paper also leave several issues for future research. The link between EIAs and hazard rates of fragmentation-based export flows has not been fully established. The trade data used herein only provide information on the trade values of a given product at the country-product level. Hence, with the currently available trade data, it is difficult to track a $\mathrm{P} \& \mathrm{C}$ once it is imported. The exported $\mathrm{P} \& \mathrm{C}$ can be used primarily for producing final goods by local companies rather than by firms operating in a GPN. Therefore, it may be prudent to investigate this link in more detail using 
firm-level data in a future study to confirm whether the finding that a strong negative relation between EIAs and the hazard rates of P\&C exports truly reflects the outsourcing activities of firms operating in a GPN.

Received 2 December 2017, Revised 15 January 2018, Accepted 6 February 2018

\section{References}

Abd-el-Rahman, Kamal. 'Firms' Competitive and National Comparative Advantages as Joint Determinant of Trade Composition.” Review of World Economics 127 (1991): 83-97.

Adam, Antonis, and Thomas Moutos. "The Trade Effects of the EU-Turkey Customs Union." The World Economy 31 (2008): 685-700.

Aitken, Norman D. "The Effect of the ECC and EFTA on European Trade: A Temporal Cross-Section Analysis." American Economic Review 63 (1973): 881-892.

Aldan, Altan, and Olcay Y. Çulha. "The Role of Extensive Margin in Exports of Turkey: A Comparative Analysis." Central Bank Review 16 (2016): 59-64.

Andersson, Thomas, and Torbjörn Fredriksson. "Distinction between Intermediate and Finished Products in Intra-Firm Trade." International Journal of Industrial Organization 18 (2000): 773-792.

Ando, Mitsuyo (2006). "Fragmentation and Vertical Intra-Industry Trade in East Asia.” North America Journal of Economics and Finance 17 (2006): 257-281. 
Antonucci, Daniele, and Stefano Manzocchi. "Does Turkey Have a Special Trade Relation with the EU?: A Gravity Model Approach.” Economic Systems 30 (2006): 157-169.

Baier, Scott L., and Jeffrey H. Bergstrand. "Do Free Trade Agreements Actually Increase Members' International Trade?" Journal of International Economics 71 (2007): 72-95.

Baier, Scott. L., Jeffrey H. Bergstrand, Peter Egger, and Patrick McLaughlin. "Do Economic Integration Agreements Actually Work? Issues in Understanding the Causes and Consequences of the Growth of Regionalism." The World Economy 31 (2008): 461-497.

Baier, Scott L., Jeffrey H. Bergstrand, and Michael Feng. "Economic Integration Agreements and the Margins of International Trade." Journal of International Economics 93 (2014): 339-350.

Bergstrand, Jeffrey H. "The Gravity Equation in International Trade: Some Microeconomic Foundation and Empirical Evidence." The Review of Economics and Statistics 67 (1985): 474-481.

Bergstrand, Jeffrey H., Mario Larch, and Yoto V. Yotov. "Economic Integration Agreements, Border Effects, Distance Elasticities in the Gravity Equation.” European Economic Review 78 (2015): 307-327.

Besedes, Tibor. "The Role of NAFTA and Returns to Scale in Export Duration." CESifo Economic Studies 59 (2013): 306-336.

Besedes, Tibor, and Juan Blyde. "What Drives Export Survival? An Analysis of Export Duration in Latin America.” Inter-American Development Bank, Washington, DC (2010).

Besedes, Tibor, and Thomas J. Prusa. "Ins, Outs and Duration of Trade." Canadian Journal of Economics 39 (2006a): 266-295. 
Besedes, Tibor, and Thomas J. Prusa. "Product Differentiation and Duration of US Import Trade.” Journal of International Economics 70 (2006b): 339-358.

Besedes, Tibor, and Thomas J. Prusa. "The Role of Extensive and Intensive Margins and Export Growth.” Journal of Development Economics 96 (2010): 371-379.

Besedes, Thomas, Juan Moreno-Cruz, and Volker Nitsch. "Trade Integration and the Fragility of Trade Relationship: Theory and Empirics." Georgia Tech Working Paper (2015).

Blyde, Juan, Alejandro Graziano, and Christian Volpe Martincus. "Economic Integration Agreements and Production Fragmentation: Evidence on the Extensive Margin.” Applied Economics Letters 22 (2015): 835-842.

Brenton, Paul, Christian Saborowski, and Erik von Uexkull. "What Explains the Low Survival Rate of Developing Country Export Flows?" World Bank Economic Review 24 (2010): 474-499.

Campa, Jose M., and Linda S. Goldberg. "The Evolving External Orientation of Manufacturing Industries: Evidence from Four Countries.” NBER Working Papers 5919 (1997).

Carrere, Celine. "Revisiting the Effects of Regional Trade Agreements on Trade Flows with Proper Specification of the Gravity Model." European Economic Review 50 (2006): 223-247.

Clark, Don P. "Country and Industry-Level Determinants of Vertical SpecializationBased Trade." International Economic Journal 20 (2006): 211-225.

Clausing, Kimberly A. "Trade Creation and Trade Diversion in the Canada-United States Free Trade Agreement.” Canadian Journal of Economics 34 (2001): 677-696. 
Corcoles, David, Carmen Diaz-Mora, and Rosario Gandoy. "Product Sophistication: A Tie that Binds Partners in International Trade." Economic Modelling 44 (2014): 533541.

Corcoles, David, Carmen Diaz-Mora, and Rosario Gandoy. "Export Survival in Global Value Chains." The World Economy 38 (2015): 1526-1554.

Corcoles, David, Carmen Diaz-Mora, and Rosario Gandoy. "Exit from Exporting: Does Being a Two-way Trader Matter?" Economics: the Open-Access, OpenAssessment E-Journal 9 (2015): 1-27.

Das, Sanghamitra, Mark J. Roberts, and James R. Tybout. "Market Entry Costs, Producer Heterogeneity and Export Dynamics." Econometrica 75 (2007): 837-873.

Egger, Hartmut, and Peter Egger. "The Determinants of EU Processing Trade." World Economy 28 (2005): 147-168.

Egger, Hartmut, Peter Egger, and David Greenaway. "The Trade Structure Effects of Endogenous Regional Trade Agreements." Journal of International Economics 74 (2008): 278-298.

Egger, Peter, Mario Larch, Kevin E. Staub, and Rainer Winkelmann. "The Trade Effects of Endogenous Preferential Trade Agreements." American Economic Journal: Economic Policy 3 (2011): 113-143.

Esteve-Perez, Silviano, Juan A. Manez-Castillejo, Maria E. Rochina-Barrachina, and Juan A. Sanchis-Llopis. "A Survival Analysis of Manufacturing Firms in Export Markets." In Entrepreneurship, Industrial Location and Economic Growth, edited by Josep Maria Arauzo-Carod, and Miguel C. Manjon-Antolin, 313-332. Cheltenham, UK, and Northampton, MA: Edward Elgar Publishing, 2007.

Feenstra, Robert C., and Gordon H. Hanson. "Globalization, Outsourcing and Wage Inequality.” The American Economic Review 86 (1996): 240-245. 
Florensa, Luis Marcelo, Laura Marquez-Ramos, and Maria Luisa Recalde. "The Effect of Economic Integration and Institutional Quality of Trade Agreements on Trade Margins; Evidence for Latin America." Review of World Economics 151 (2015): 329-351.

Foster, Neil, Johannes Poeschl, and Robert Stehrer. "The Impact of Preferential Trade Agreements on the Margins of International Trade.” Economic Systems 35 (2011): 8497.

Frankel, Jeffrey Alexander, Ernesto Stein, and Shang-Jin Wei. "Trading Blocs and the Americas: The Natural, the Unnatural and the Super-Natural?" Journal of Development Economics 47 (1995): 61-95.

Frede, Julian, and Hakan Yetkiner. "The Regional Trade Dynamics of Turkey: A Panel Data Gravity Model.” The Journal of International Trade\&Economic Development 26 (2017): 633-648.

Freund, Caroline, and Emanuel Ornelas. "Regional Trade Agreements." The Annual Review of Economics 2 (2010): 139-167.

Fugazza, Marco, and Ana Cristina Molina. "On the Determinants of Exports Survival." Canadian Journal of Development Studies 37 (2016): 159-177.

Gaulier, Guillaume, and Soledad Zignago. "BACI: International Trade Database at the Product-Level. The 1994-2007 Version.” CEPII Working Paper no. 2010-23 (2010).

Ghosh, Sucharita, and Steven Yamarik. "Does Trade Creation Measure Up? A Reexamination of the Effects of Regional Trading Arrangements." Economics Letters 82 (2004): 213-219.

Görg, Holger. "Fragmentation and Trade: US Inward Processing Trade in the EU." Review of World Economics 136 (2000): 403-422. 
Greenaway, David, Robert Hine, and Chris Milner. "Country-Specific Factors and the Pattern of Horizontal and Vertical Intra-Industry Trade in the UK." Review of World Economics 130 (1994): 77-100.

Greenaway, David, Robert Hine, and Chris Milner. "Vertical and Horizontal IntraIndustry Trade: A Cross Industry Analysis for the United Kingdom." Economic Journal 105 (1995): 1505-1518.

Grossman, Gene M., and Elhanan Helpman. "Outsourcing in a Global Economy." Review of Economic Studies 72 (2005): 135-59.

Gündoğdu, Ceren, and Dürdane Şirin S. "Participation of Turkey in Global Value Chains: An Analysis Based on World Input Output Database.” ERC Working Papers in Economics no. 16/10 (2016).

Johnson, Robert C., and Guillermo Noguera. “Accounting for Intermediates: Production Sharing and Trade in Value Added." Journal of International Economics 86 (2012): 224-236.

Jones, Ronald W., and Henryk Kierzkowski. “A Framework for Fragmentation.” In Fragmentation: New Production Patterns in the World Economy, edited by Sven W. Arndt, and Henryk Kierzkowski, 17-34. Oxford: Oxford University Press, 2001.

Jones, Ronald W., Henryk Kierzkowski, and Gregory Leonard. "Fragmentation and Intra-Industry Trade." In Frontiers of Research in Intra-Industry Trade, edited by P.J. Lloyd and Hyun-Hoon Lee,67-86. New York: Palgrave Macmillan Ltd, 2002.

Hayakawa, Kazunobu, and Nobuaki Yamashita. "The Role of Preferential Trade Agreements (PTAs) in Facilitating Global Production Networks." Journal of World Trade 45 (2011): 1181-1207.

Hess, Wolfgang, and Maria Persson. "The Duration of Trade Revisited. ContinuousTime vs. Discrete-Time Hazards.” Empirical Economics 43 (2011a): 1083-1107. 
Hess, Wolfgang, and Maria Persson. "Exploring the Duration of EU Imports." Review of World Economics 147 (2011b): 665-692.

Hummels, David and Peter J. Klenow. “The Variety and Quality of a Nation's Exports." American Economic Review 95 (2005): 704-723.

Hummels, David, Jun Ishii, and Kei-Mu Yi. "The Nature and Growth of Vertical Specialization in World Trade.” Journal of International Economics 54 (2001): 75-96.

Kaminski, Bartlomiej, and Francis Ng. “Turkey's Evolving Trade Integration into PanEuropean Markets.” The World Bank Policy Research Working Paper Series no. 3908 (2006).

Kamuganga, Dick Nuwamanya. "Does Intra-African Regional Trade Cooperation Enhance Export Survival?" Graduate Institute of International and Development Studies Working Paper No: 16/2012 (2012).

Kimura, Fukunari, and Mitsuyo Ando. "Two-dimensional Fragmentation in East Asia: Conceptual Framework and Empirics." International Review of Economics and Finance 14 (2005): 317-348.

Kimura, Fukunari, Yuya Takahashi, Y., and Kazunobu Hayakawa. "Fragmentation and Parts and Components Trade: Comparison between East Asia and Europe." North American Journal of Economics and Finance 18 (2007): 23-40.

Kimura, Fukunari, and Ayako Obashi. "International Production Networks in Machinery Industries: Structure and Its Evolution.” ERIA Discussion Paper Series no. 2010-09 (2010).

Magee, Christopher S. P. "New Measures of Trade Creation and Trade Diversion." Journal of International Economics 75 (2008): 349-362. 
Magee, Christopher S. P. "Trade Creation, Trade Diversion, and the General Equilibrium Effects of Regional Trade Agreements: A Study of the European Community-Turkey Customs Union.” Review of World Economics 152 (2016): 383399.

Martuscelli, Antonio, and Gonzalo Varela. "Survival is for Fittest: Export Survival Patterns in Georgia.” The World Bank Policy Research Working Paper Series no. 7161 (2015).

Melitz, Marc J. "The Impact of Trade on Intra-Industry Reallocations and Aggregate Industry Productivity.” Econometrica 71 (2003): 1695-1725.

Neyaptı, Bilin, Fatma Taşkın, and Murat Üngör. "Has European Customs Union Agreement Really Affected Turkey’s Trade?" Applied Economics 39 (2007): 21212132.

Nitsch, Volker. "Die Another Day: Duration in German Import Trade." Review of World Economics 145 (2009): 133-154.

Nowak-Lehmann, Felicitas, Dierk Herzer, Inmaculada Martinez-Zarzoso, and Sebastian Vollmer. "The Impact of a Customs Union between Turkey and the EU on Turkey's Exports to the EU.” Journal of Common Market Studies 45 (2007): 719-743.

Obashi, Ayako. "Stability of Production Networks in East Asia: Duration and Survival of Trade." Japan and the World Economy 22 (2010): 21-30.

OECD. “OECD Economic Surveys: Turkey.” OECD Publishing, Paris, 2016.

Rauch, James E., and Joel Watson. "Starting Small in an Unfamiliar Environment." International Journal of Industrial Organization 21 (2003): 1021-142. 
Recalde, M. Luisa, Luis M. Florensa, and Pedro Gabriel D. "Latin American Integration and the Survival of Trade Relationship." $17^{\text {th }}$ European Trade Study Group (ETSG) Conference, Helsinki (Finland), September 2016.

Shao, Jun, Kangning $\mathrm{Xu}$, and Bin Qui. “Analysis of Chinese Manufacturing Export Duration." China \& World Economy 20 (2012): 56-73.

Stirbat, Liviu, Richard Record, and Konesawang Nghardsaysone. "The Experience of Survival: Determinants of Export Survival in Lao PDR." World Development 76 (2015): 82-94.

Wakasugi, Ryuhei. "Vertical Intra-Industry Trade and Economic Integration in East Asia." Asian Economic Papers 6 (2007): 26-36.

World Bank. "Evaluation of the EU-Turkey Customs Union.” World Bank Report No. 85830-TR (2014a).

World Bank. "Trading up to High Income: Turkey Country Economic Memorandum." World Bank Report No.82307-TR (2014b).

Yeats, Alexander J. "How Big is Global Production Sharing?" In Fragmentation: New Production Patterns in the World Economy, edited by Sven W. Arndt, and Henryk Kierzkowski, 108-144, Oxford: Oxford University Press, 2001.

Y1lmaz, Kamil. "Taking Stock: The Customs Union between Turkey and the EU Fifteen Years Later.” South European Society and Politics 16 (2011): 235-249.

Yi, Kei-Mu. "Can Vertical Specialization Explain the Growth of World Trade?" Journal of Political Economy 111 (2003): 52-102. 


\section{Appendices}

\section{Appendix 1: List of countries}

\begin{tabular}{|l|l|l|l|}
\hline Afghanistan & Djibouti & Kyrgyzstan & Rwanda \\
\hline Albania & Dominica & Lao PDR & St. Kitts \& Nevis \\
\hline Algeria & Dominican Republic & Latvia & St. Lucia \\
\hline Andorra & East Timor & Lebanon & St. Vincent \& Grenadines \\
\hline Angola & Ecuador & Liberia & Samoa \\
\hline Antigua \& Barbuda & Egypt & Libya & San Marino \\
\hline Argentina & El Salvador & Lithuania & Sao Tome \& Principe \\
\hline Armenia & Equatorial Guinea & China, Macau & Saudi Arabia \\
\hline Aruba & Eritrea & Madagascar & Senegal \\
\hline Australia & Estonia & Malawi & Serbia \\
\hline Austria & Ethiopia & Malaysia & Seychelles \\
\hline Azerbaijan & Fiji & Maldives & Sierra Leone \\
\hline Bahamas & Finland & Mali & Singapore \\
\hline Bahrain & France & Malta & Slovakia \\
\hline Bangladesh & French Polynesia & Marshall Islands & Slovenia \\
\hline Barbados & Gabon & Mauritania & Solomon Islands \\
\hline Belarus & Gambia & Mauritius & South Africa \\
\hline Belgium-Luxembourg & Georgia & Mexico & Spain \\
\hline Belize & Germany & Micronesia & Sri Lanka \\
\hline Benin & Ghana & Moldova & Suriname \\
\hline Bermuda & Greece & Mongolia & Sweden \\
\hline Bhutan & Greenland & Montenegro & Switzerland \\
\hline Bolivia & Grenada & Morocco & Syria \\
\hline Bosnia \& Herzegovina & Guatemala & Mozambique & Tajikistan \\
\hline Brunei Darussalam & Guinea & Myanmar & Tanzania \\
\hline Bulgaria & Guinea-Bissau & Nepal & Thailand \\
\hline Burkina Faso & Guyana & Netherlands & TFYR of Macedonia \\
\hline Burundi & Haiti & New Caledonia & Togo \\
\hline Cambodia & Honduras & New Zealand & Tonga \\
\hline & & & \\
\hline
\end{tabular}


(continued)

\begin{tabular}{|l|l|l|l|}
\hline Cameroon & China, Hong Kong & Nicaragua & Trinidad \& Tobago \\
\hline Canada & Hungary & Niger & Tunisia \\
\hline Cape Verde & Iceland & Nigeria & Turkmenistan \\
\hline $\begin{array}{l}\text { Central African } \\
\text { Republic }\end{array}$ & India & $\begin{array}{l}\text { Northern Mariana } \\
\text { Islands }\end{array}$ & Tuvalu \\
\hline Chad & Indonesia & Norway & Uganda \\
\hline Chile & Iran & Oman & Ukraine \\
\hline China & Iraq & Pakistan & United Arab Emirates \\
\hline Colombia & Ireland & Palau & United Kingdom \\
\hline Comoros & Israel & Panama & USA \\
\hline Congo (Rep.) & Italy & Papua New Guinea & Uruguay \\
\hline Congo (Dem. Rep.) & Jamaica & Paraguay & Uzbekistan \\
\hline Costa Rica & Japan & Peru & Vanuatu \\
\hline Côte d'Ivoire & Jordan & Philippines & Venezuela \\
\hline Croatia & Kazakhstan & Poland & Vietnam \\
\hline Cuba & Kenya & Portugal & Yemen \\
\hline Cyprus & Kiribati & Qatar & Zambia \\
\hline Czech Republic & Korea (Rep.) & Romania & Zimbabwe \\
\hline Denmark & Kuwait & Russia & \\
\hline
\end{tabular}


Appendix 2: List of EIAs signed by Turkey

\begin{tabular}{|c|c|c|c|c|c|c|c|}
\hline Country & Type & Entry & $\begin{array}{c}\text { Phased } \\
\text { out }\end{array}$ & Country & Type & Entry & $\begin{array}{c}\text { Phased } \\
\text { out }\end{array}$ \\
\hline Afghanistan & PTA & 2008 & & Japan & NR-PTA & 1972 & \\
\hline Albania & FTA & 2008 & & Jordan & FTA & 2011 & \\
\hline Australia & NR-PTA & 1974 & & Kazakhstan & PTA & 2008 & \\
\hline Austria & NR-PTA & 1972 & 1993 & Kyrgyzstan & PTA & 2008 & \\
\hline Austria & FTA & 1993 & 1995 & Latvia & FTA & 2001 & 2004 \\
\hline Austria & $\mathrm{CU}$ & 1995 & & Latvia & $\mathrm{CU}$ & 2004 & \\
\hline Azerbaijan & PTA & 2008 & & Lithuania & FTA & 1999 & 2004 \\
\hline Bangladesh & PTA & 2011 & & Lithuania & $\mathrm{CU}$ & 2004 & \\
\hline Belarus & NR-PTA & 2010 & & Macedonia & FTA & 2000 & \\
\hline Belgium & PTA & 1973 & 1996 & Malaysia & PTA & 2011 & \\
\hline Belgium & $\mathrm{CU}$ & 1996 & & Malaysia & FTA & 2016 & \\
\hline Luxembourg & PTA & 1973 & 1996 & Malta & $\mathrm{CU}$ & 2004 & \\
\hline Luxembourg & $\mathrm{CU}$ & 1996 & & Mauritius & FTA & 2012 & \\
\hline $\begin{array}{l}\text { Bosnia \& } \\
\text { Herzegovina }\end{array}$ & FTA & 2003 & & Moldova & FTA & 2016 & \\
\hline Bulgaria & FTA & 1999 & 2007 & Montenegro & FTA & 2010 & \\
\hline Bulgaria & $\mathrm{CU}$ & 2007 & & Morocco & FTA & 2006 & \\
\hline Canada & NR-PTA & 1974 & & Netherlands & PTA & 1973 & 1996 \\
\hline Chile & FTA & 2011 & & Netherlands & $\mathrm{CU}$ & 1996 & \\
\hline Croatia & FTA & 2004 & 2013 & New Zealand & NR-PTA & 1972 & \\
\hline Croatia & $\mathrm{CU}$ & 2013 & & Nigeria & PTA & 2011 & \\
\hline Cyprus & $\mathrm{CU}$ & 2004 & & Norway & NR-PTA & 1977 & 1993 \\
\hline Czech Rep. & FTA & 1997 & 2004 & Norway & FTA & 1993 & \\
\hline Czech Rep. & $\mathrm{CU}$ & 2004 & & Pakistan & PTA & 1991 & \\
\hline Slovak Rep. & FTA & 1999 & 2004 & Palestine & FTA & 2005 & \\
\hline Slovak Rep. & $\mathrm{CU}$ & 2004 & & Poland & NR-PTA & 1981 & 1990 \\
\hline Denmark & PTA & 1973 & 1996 & Poland & FTA & 2000 & 2004 \\
\hline Denmark & $\mathrm{CU}$ & 1996 & & Poland & $\mathrm{CU}$ & 2004 & \\
\hline Egypt & FTA & 2007 & & Portugal & $\mathrm{CU}$ & 1996 & \\
\hline Estonia & FTA & 1999 & 2004 & Romania & FTA & 1998 & 2007 \\
\hline
\end{tabular}


(continued)

\begin{tabular}{|l|c|c|c|l|c|c|c|}
\hline Country & Type & Entry & $\begin{array}{c}\text { Phased } \\
\text { out }\end{array}$ & Country & Type & Entry & $\begin{array}{c}\text { Phased } \\
\text { out }\end{array}$ \\
\hline Estonia & CU & 2004 & & Romania & CU & 2007 & \\
\hline Finland & NR-PTA & 1977 & 1993 & Russia & NR-PTA & 2010 & \\
\hline Finland & FTA & 1993 & 1996 & Serbia & FTA & 2010 & \\
\hline Finland & CU & 1996 & & Slovenia & FTA & 2001 & 2004 \\
\hline France & PTA & 1973 & 1996 & Slovenia & CU & 2004 & \\
\hline France & CU & 1996 & & Spain & PTA & 1986 & 1996 \\
\hline Georgia & FTA & 2008 & & Spain & CU & 1996 & \\
\hline Germany & PTA & 1973 & 1996 & South Korea & FTA & 2013 & \\
\hline Germany & CU & 1996 & & Sweden & NR-PTA & 1978 & 1993 \\
\hline Greece & PTA & 1981 & 1996 & Sweden & FTA & 1993 & 1996 \\
\hline Greece & CU & 1996 & & Sweden & CU & 1996 & \\
\hline Hungary & FTA & 1998 & 2004 & Switzerland & NR-PTA & 1972 & 1992 \\
\hline Hungary & CU & 2004 & & Switzerland & FTA & 1992 & \\
\hline Iceland & FTA & 1993 & & Syria & FTA & 2007 & 2012 \\
\hline Indonesia & PTA & 2011 & & Tajikistan & PTA & 2008 & \\
\hline Iran & PTA & 1991 & & Tunisia & FTA & 2005 & \\
\hline Ireland & PTA & 1973 & 1996 & Turkmenistan & PTA & 2008 & \\
\hline Ireland & CU & 1996 & & UK & PTA & 1973 & 1996 \\
\hline Israel & FTA & 1997 & & UK & CU & 1996 & \\
\hline Italy & PTA & 1973 & 1996 & USA & NR-PTA & 1976 & \\
\hline Italy & CU & 1996 & & Uzbekistan & PTA & 2008 & \\
\hline & & & & & & & \\
\hline
\end{tabular}

(Note) "Entry" refers to the year in which the EIA was enforced, while "phased out" indicates the year in which the EIA ended. Data on various EIAs is mainly retrieved from Jeffry Bergstrand's website and supplemented with additional data from the WTO's website. 


\section{Appendix 3: Variable definitions and data sources}

\begin{tabular}{|c|c|c|}
\hline Variable & Definition & Data source \\
\hline Log distance & $\begin{array}{l}\text { Log of the distance in kilometers be- } \\
\text { tween Turkey's capital (Ankara) and its } \\
\text { trading partner's capital }\end{array}$ & $\begin{array}{l}\text { CEPII's GeoDist database: } \\
\text { http://www.cepii.fr }\end{array}$ \\
\hline Common language & $\begin{array}{l}\text { Takes the value one if Turkey and } \\
\text { its trading partner share a common } \\
\text { language, and zero otherwise }\end{array}$ & $\begin{array}{l}\text { CEPII's GeoDist database: } \\
\text { http://www.cepii.fr }\end{array}$ \\
\hline Common border & $\begin{array}{l}\text { Takes the value one if Turkey and } \\
\text { its trading partner share a common } \\
\text { border, and zero otherwise }\end{array}$ & $\begin{array}{l}\text { CEPII's GeoDist database: } \\
\text { http://www.cepii.fr }\end{array}$ \\
\hline Log GDP (importer) & $\begin{array}{l}\text { Log of importer's GDP, measured in } \\
\text { nominal USD }\end{array}$ & $\begin{array}{l}\text { World Bank's World Develop- } \\
\text { ment Indicators (WDI) }\end{array}$ \\
\hline $\begin{array}{l}\text { Log initial export } \\
\text { value }\end{array}$ & $\begin{array}{l}\text { Log of the value of exports at the start } \\
\text { of the spell, measured in USD }\end{array}$ & $\begin{array}{l}\text { CEPII's BACI database: } \\
\text { http://www.cepii.fr }\end{array}$ \\
\hline Lagged duration & $\begin{array}{l}\text { Number of years for which the previous } \\
\text { spell of the same export relation lasted }\end{array}$ & $\begin{array}{l}\text { CEPII's BACI database: } \\
\text { http://www.cepii.fr }\end{array}$ \\
\hline EIA exists & $\begin{array}{l}\text { Takes the value one if Turkey and its } \\
\text { partners have an agreement at some } \\
\text { point, and zero otherwise. }\end{array}$ & $\begin{array}{l}\text { Baier and Bergstrand's website: } \\
\text { www.nd.edu/jbergstr and } \\
\text { WTO's RTA-IS database. }\end{array}$ \\
\hline EIA in effect & $\begin{array}{l}\text { Takes the value one if Turkey and its } \\
\text { partners have an agreement in the given } \\
\text { calendar year, and zero otherwise. }\end{array}$ & $\begin{array}{l}\text { Baier and Bergstrand's website: } \\
\text { www.nd.edu/jbergstr and } \\
\text { WTO's RTA-IS database. }\end{array}$ \\
\hline Spell starts after EIA & $\begin{array}{l}\text { Takes the value one if an export spell } \\
\text { starts after the agreement is signed, and } \\
\text { zero otherwise }\end{array}$ & $\begin{array}{l}\text { BACI database, Baier and Berg- } \\
\text { strand's website: Www.nd.edu/ } \\
\text { jbergstr and WTO's RTA-IS } \\
\text { database. }\end{array}$ \\
\hline Duration of EIA & $\begin{array}{l}\text { Measures how long an agreement is in } \\
\text { place (in years) }\end{array}$ & $\begin{array}{l}\text { Baier and Bergstrand's website: } \\
\text { www.nd.edu/jbergstr and } \\
\text { WTO's RTA-IS database. }\end{array}$ \\
\hline$V D$ & $\begin{array}{l}\text { Takes the value one if the 6-digit prod- } \\
\text { uct flow shows evidence of VD in the } \\
\text { given calendar year, and zero otherwise }\end{array}$ & $\begin{array}{l}\text { CEPII's BACI database: } \\
\text { http://www.cepii.fr }\end{array}$ \\
\hline
\end{tabular}

